\title{
Structure and functioning of the anthropogenically transformed Comacchio lagoonal ecosystem (Ferrara, Italy)
}

\author{
Yu. I. Sorokin*, P. Yu. Sorokin*, A. Gnes \\ SIVALCO Laboratory, Corso Mazzini 200, Comacchio, I-44022 Ferrara, Italy
}

\begin{abstract}
Since 1985, the lagoons of Comacchio, in the coastal area of the NW Adriatic Sea, have been experiencing an ecological catastrophe caused by an extremely dense bloom of picocyanobacteria. The bloom has resulted in a drastic depletion of all kinds of zooplankton, including protozoa. It has caused mass mortality of benthic fauna and the collapse of valuable eel and mullet fisheries. The ecosystem of these lagoons, being thus completely transformed and deprived of animal components of its food web, appears to be remarkably stable on annual and seasonal scales. Its main functional component is the phytoplankton community dominated by several species of picocyanobacteria of the genera Coelosphaerium. Aphanothece and Synechococcus. In this paper quantifications of the main components of the plankton are presented together with data on standing stocks of organic matter and its cycling, and on the cycling of phosphorus and sulfur. The energy balances of the ecosystem are calculated and energy flow schemes derived. The mechanism of the extreme stability of this new kind of aquatic ecosystem and a probable scenario of its orngin are discussed
\end{abstract}

KEY WORDS: Lagoonal ecology A Aquaculture Cyanobacteria - Eutrophication - Microplankton

\section{INTRODUCTION}

The Comacchio lagoonal system is situated in the coastal zone of the Northwestern Adriatic Sea $25 \mathrm{~km}$ north of Ravenna. It is separated from the sea by the $2.5 \mathrm{~km}$ wide Spina spit (Fig. 1) and includes the Magnavacca lagoon, $8 \mathrm{~km}$ in diameter, and the Campo lagoon, $2 \mathrm{~km}$ in diameter. The lagoons are connected with the Adriatic Sea by 2 marine channels (Fig. 1). They have a salinity of 30 to $38 \%$ and depth range of 0.8 to $1.5 \mathrm{~m}$. For centuries they were among the most valuable fishing grounds in Italy, being rich in eels, mullets, clams, shrimps and other animals. However, during the last decade they have been experiencing an ecological catastrophe caused by an extremely dense chronic bloom of picocyanobacteria. The bloom began

- Present address: Southern Dept of Oceanology Institute RAS, Gelendzhik-7, Krasnodar district, 353470, Russia.

E-mail:kosyan@sdios.sea.ru in 1985 and resulted in depletion of zooplankton and of zoo- and macro-phytobenthos. Finally it also caused fish mortality. These developments led to a drastic collapse of all kinds of fishery.

Initial studies on the environmental situation in the lagoons in August 1993 revealed a previously unknown kind of ecological collapse. A formerly productive and healthy lagoonal ecosystem degenerated into one practically devoid of a food web or animal grazers and producing chiefly cyanobacterial biomass in the water column and hydrogen sulfide in bottom sediments, both toxic for aquatic fauna. The processes leading to the build-up of cyanobacterial biomass and hydrogen sulfide production are interconnected thus providing a stability in time over seasons and years unusual for any temperate natural aquatic system. This transformed ecosystem has not shown any signs of seasonal succession since 1985. This phenomenon deserved careful study. The present research was carried out during summer (August to September) and November 1993. 


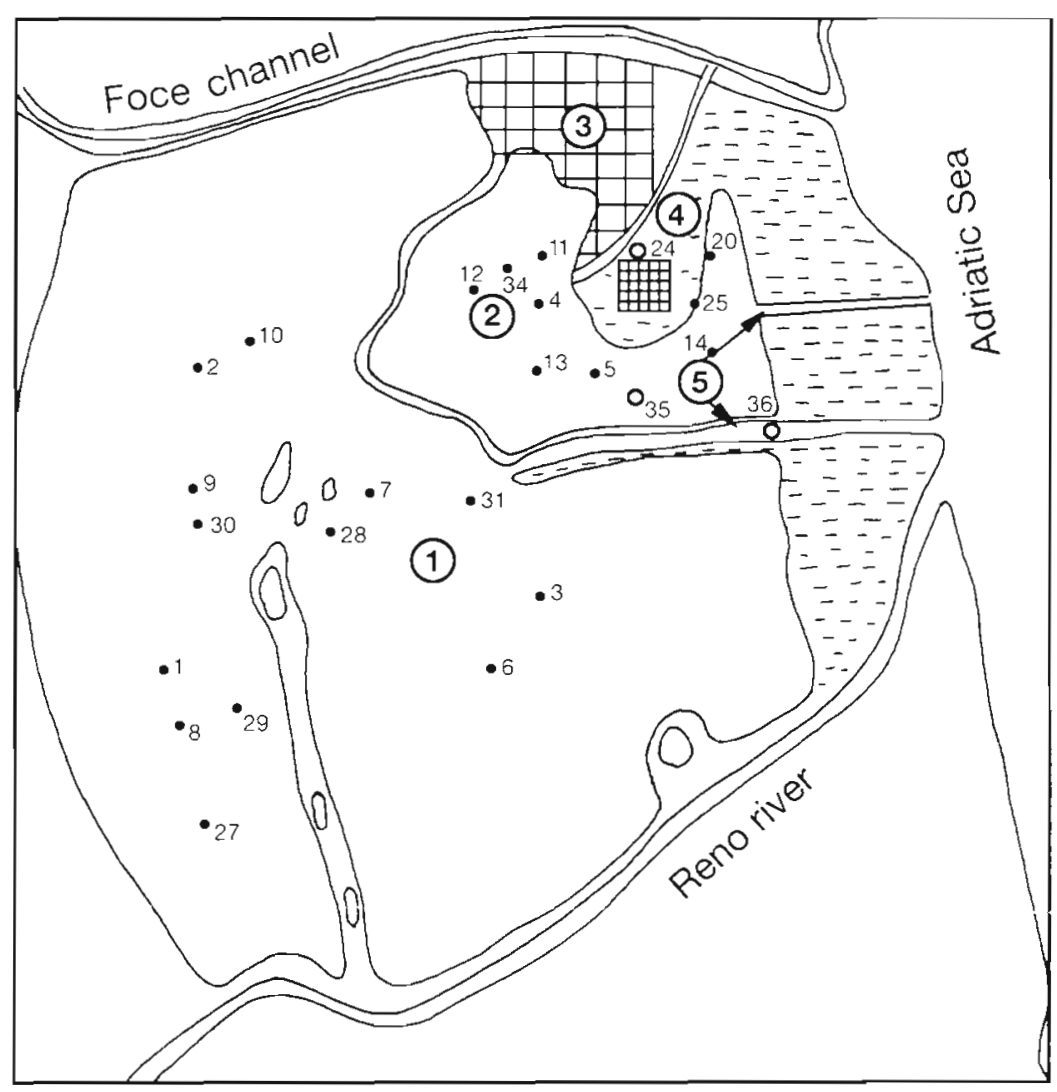

Fig. 1. Schematic map of the Comacchio lagoons and positions of stations. Encircled numbers: 1, lagoon of Magnavacca 2 2, lagoon of Campo; 3, lagoons of Salina; 4 , intensive fish culture plant of SIVALCO and Laboratory; 5 , marine channels present in the sample. Mesozooplankton was collected by passing 801 of water through a $40 \mu \mathrm{m}$ mesh plankton net.

The primary production of phytoplankton was estimated a using modified radiocarbon method (Sorokin 1960 . 1987). Samples for measuring the photosynthetic rate in the surface layer $\left(C_{p s}\right)$ were exposed to natural illumination in situ for $2 \mathrm{~h}$ during the second half of the light day. For the calculation of primary production per whole day we used empirical curves of its diurnal course (Fig. 2). To estimate the primary production per $\mathrm{m}^{2}$ in the water column empirically estimated $K_{t}$ curves were used (see Fig. 3). These curves describe the dependence of the relative photosynthesis rate along a vertical profile in the water column upon the light attenuation within the deptì (Sorokin 1960). They were estimated experimentally by exposure of bottles containing identical water samples at different depths in situ. We did not correct for its dependence also upon the vertical distribution of active phytoplankton ( $K_{\mathrm{p}}$-curves), because the latter appeared to be quite even in these shallow lagoons.

\section{MATERIALS AND METHODS}

Samples of water and bottom sediments were taken in the main Comacchio lagoons in August at Stns 1 to 5, in September at Stns 6 to 14 and in November at Stns 27 to 31 and 33. For positions of stations, see Fig. 1. Stns 24 to 26 were situated around the fish culture plant: Stn 24 in front of the entrance, Stn 25 in the exit channel pond, and Stn 26 in the exit intermedial pond. Stn 36 was situated in the Bellocchio marine channel through which Adriatic water enters the lagoons.

Phytoplankton numbers and average sizes of cells within size groups were estimated after Caron (1983) by epifluorescence microscopy on black Nuclepore filters stained with the primuline fluorochrome. Bacterioplankton was likewise quantified after Hobbie et al. (1977). Zooflagellates were counted on the same filters prepared for counts of phytoplankton. Viable ciliates were quantified by counting in chambers $4 \mathrm{~mm}$ deep and $15 \mathrm{ml}$ in volume after Sorokin (1980). The same chamber was used to count rotifers if any were

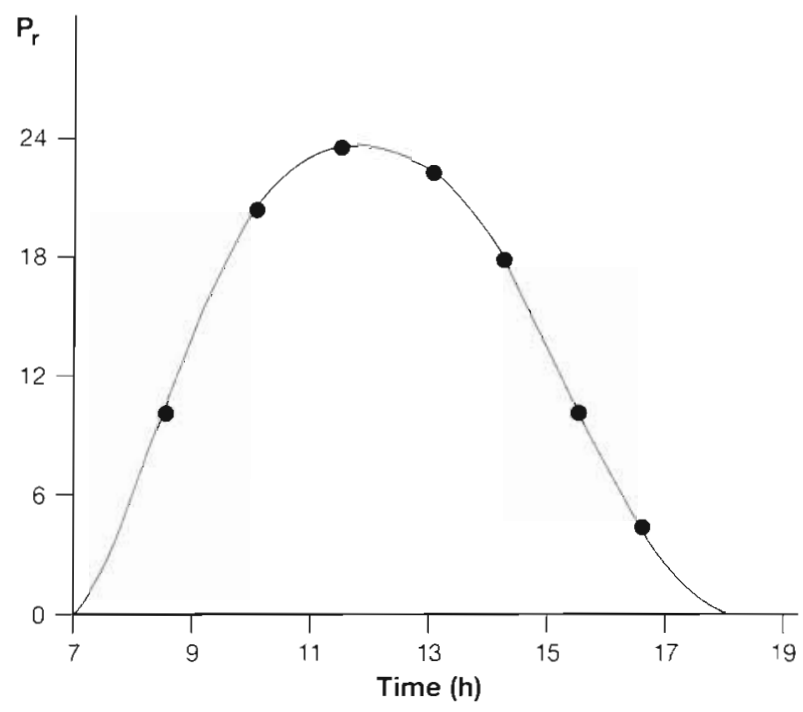

Fig. 2. Diurnal course of photosynthesis rate in water sample from the Magnavacca Iagoon in September; $P_{r}$ : relative rate of photosynthesis 
The production of bacterioplankton was measured by the dark ${ }^{14} \mathrm{C}$ uptake method of Romanenko modified by Sorokin (1990). The total plankton respiration (decomposition, $M_{1}$ ) was estimated as dissolved oxygen uptake rate in water samples contained in $250 \mathrm{ml}$ bottles by their exposure (in triplicate) for $6 \mathrm{~h}$ at the in situ temperature. The oxygen content in these experiments was measured by Winkler titration. Uptake rates $\left(A_{t}\right)$ and turnover time (TP) were estimated with the aid of ${ }^{32} \mathrm{PO}_{4}$-P as label (Sorokin 1985). The stock of labile organic matter (LOM) in water was estimated with the use of the BOD-30 method after Sorokin \& Mamaeva (1980). The original water samples for this analysis were diluted 1:20 with double distilled water. The BOD-30 in the distilled water used was accounted for during the calculations. The value of LOM stock (SL) was calculated in units of carbon as: $\mathrm{SL}=0.55$ $\mathrm{BOD}-30 \mathrm{mg} \mathrm{l}^{-1}$. The suspended organic matter content in water was analysed by wet chromic combustion on glass fiber filters, using chromic acid solution in concentrated $(95 \%) \mathrm{H}_{2} \mathrm{SO}_{4}$ containing a trace of $\mathrm{AgSO}_{4}$. The samples were combusted at $135^{\circ} \mathrm{C}$ for $30 \mathrm{~min}$, and titrated iodometrically after cooling. The content of organic matter in bottom sediments was measured by the same method after previous exposure of the dried samples to concentrated phosphoric acid for $1 \mathrm{~d}$ to dissipate chlorides. The stock of acidsoluble sulfides in sediments was measured in samples of mud in which the sulfides were previously fixed with a mixture of $\mathrm{ZnSO}_{4}+\mathrm{Na}_{2} \mathrm{CO}_{3}$. The hydrogen sulfide was distilled out from the acidified sediments and trapped with $\mathrm{Cd}$-acetate $+\mathrm{Na}_{2} \mathrm{CO}_{3}$ solution after Sorokin (1975). Then the sulfide in this mixture was estimated by iodometric titration. The rate of $\mathrm{H}_{2} \mathrm{~S}$ production in sediments due to the microbial sulfate reduction was estimated with the use of labeled sulfate, ${ }^{35} \mathrm{SO}_{4}$, after Sorokin (1982).

All estimations of $C, P$ and $S$ uptake or turnover rates were made in duplicate. In the tables mean values are given to an accuracy of \pm 5 to $8 \% \mathrm{SD}$. The stations represented in the tables were selected to cover the ranges of parameters measured in the lagoons.

\section{RESULTS}

\section{Phytoplankton and primary production}

The data on phytoplankton density and composition (Table 1) show in both main lagoons, in both summer and late autumn, a highly dense bloom of picocyanobacteria without substantial differences except for a decrease in density from 140 to $300 \mathrm{~g}$ $\mathrm{m}^{-3}$ in late summer to 50 to $140 \mathrm{~g} \mathrm{~m}^{-3}$ in late autumn. However even the latter lower level of phytoplankton density is at least 3 to 5 times more than that found during an ordinary seasonal bloom or even in 'red tide' blooms in eutrophic coastal marine waters or in upwelling areas. The density of phytoplankton in August-September was above any previously recorded numbers in natural marine lagoonal or coastal waters. At most stations it was over $100 \mathrm{~g} \mathrm{~m}^{-3}$, while at some of them it was over $200 \mathrm{~g} \mathrm{~m}^{-2}$. The numbers of picocyanobacteria in August were over $100 \times 10^{6}$ cells $\mathrm{ml}^{-1}$, and in September-November over $30 \times 10^{6} \mathrm{ml}^{-1}$.

Table 1. Number $(\mathrm{N})$ and biomass $\left(\mathrm{B}, \mathrm{g} \mathrm{m}^{-3}\right)$ of the main phytoplankton groups in the Comacchio lagoons

\begin{tabular}{|c|c|c|c|c|c|c|c|c|c|c|c|}
\hline \multirow{3}{*}{ Month } & \multirow{3}{*}{ Lagoon } & \multirow[t]{3}{*}{ Strn no. } & \multicolumn{4}{|c|}{ Cyanobacteria } & \multicolumn{4}{|c|}{ Eucaryotic algae } & \multirow{3}{*}{$\begin{array}{c}\text { Total } \\
\text { biomass } \\
\left(9 \mathrm{~m}^{-3}\right)\end{array}$} \\
\hline & & & Pico & & Nane & & Pico & & Nano + & Micro & \\
\hline & & & $\mathrm{N}\left(10^{6} \mathrm{~m}^{-1}\right)$ & B & $\mathrm{N}\left(10^{b} \mathrm{ml}^{-1}\right)$ & $B$ & $N\left(10^{6} \mathrm{l}^{-1}\right)$ & B & $N\left(10^{6} 1^{-1}\right)$ & B & \\
\hline \multirow[t]{5}{*}{ August } & Magnavacca & 1 & 139 & 262 & 2.4 & 30 & 140 & 0.9 & 3.17 & 0.7 & 293.6 \\
\hline & & 2 & 143 & 333 & 1.7 & 23 & 128 & 0.8 & 3.40 & 0.6 & 358.2 \\
\hline & & 3 & 144 & 226 & 1.2 & 16 & 133 & 0.8 & 3.32 & 0.7 & 243.5 \\
\hline & Campo & 4 & 69 & 169 & 0.9 & 11 & 117 & 0.6 & 3.51 & 0.7 & 181.3 \\
\hline & & 5 & 66 & 130 & 0.6 & 7 & 165 & 2.2 & 3.80 & 0.8 & 140.0 \\
\hline \multirow[t]{6}{*}{ September } & Magnavacca & 7 & 53 & 91 & 1.1 & 28 & 293 & 8.2 & 5.70 & 1.3 & 128.5 \\
\hline & & 8 & 96 & 164 & 2.3 & 46 & 550 & 11.0 & 6.33 & 1.1 & 222.1 \\
\hline & & 10 & 46 & 78 & 0.6 & 11 & 455 & 8.0 & 3.80 & 0.8 & 97.8 \\
\hline & Campo & 12 & 53 & 100 & 0.1 & 1 & 120 & 1.4 & 9.50 & 1.9 & 104.3 \\
\hline & & 14 & 24 & 45 & 0.4 & 7 & 710 & 12.8 & 7.20 & 1.4 & 66.2 \\
\hline & Marine channel & 36 & 0.02 & 0.04 & 0 & 0 & 0.32 & 0.03 & 0.36 & 1.3 & 1.37 \\
\hline \multirow[t]{5}{*}{ November } & Magnavacca & 27 & 76 & 132 & 0.3 & 5 & 124 & 2.2 & 3.40 & 0.8 & 140.0 \\
\hline & & 29 & 30 & 62 & 0.2 & 3 & 350 & 6.3 & 6.75 & 1.5 & 72.8 \\
\hline & & 30 & 18 & 35 & 0.2 & 4 & 620 & 12.3 & 2.60 & 0.6 & 51.9 \\
\hline & Campo & 34 & 33 & 67 & 0.2 & 3 & 330 & 7.2 & 1.46 & 3.1 & 79.3 \\
\hline & & 35 & 34 & 68 & 0.1 & 2 & 260 & 5.7 & 3.54 & 0.8 & 76.5 \\
\hline
\end{tabular}


Over $97 \%$ of total phytoplankton biomass was formed by picocyanobacteria in August, and over $80 \%$ in September and November. The cyanobacteria, which had cells of 1 to $3 \mu \mathrm{m}$ size, were randomly distributed within their mucous colonies. Their populations were dominated by 2 species of Coelosphaerium with small cells, C. kutzengianum (a potentially toxic species) and $C$. minutissimum, and by Synechococcus sp. Their nano-fraction was represented mostly by Aphanothece salina, which also forms mucous colonies. A minor eucaryotic fraction of phytocoenosis was represented by Chlorella marina, nanophytoflagellates and rare gymnodiid dinoflagellates. In November the composition of phytocoene did not significantly change in comparison with that observed in August-September.

Primary production in the upper water layer 0 to $5 \mathrm{~cm}$ ) in the lagoons was extremely high, within the range 0.7 to $3.5 \mathrm{mg} \mathrm{C}^{-1}$ both in summer and in late autumn (see Table 4). At most stations it exceeded $1.5 \mathrm{mg} \mathrm{C} \mathrm{l}^{-1} \mathrm{~d}^{2}$ - the highest ever recorded rates in the upper layer of coastal eutrophic marine basins or in upwelling areas. But in the latter such high levels of primary production were achieved by phytoplankton populations 10 to 20 times less dense than those observed in the Comacchio lagoons, e.g. by a phytoplankton biomass of 5 to $20 \mathrm{~g} \mathrm{~m}^{-3}$. In fact, the specific photosynthetic production coefficients (P/B) calculated for upper water layers of the lagoons appeared to be very low even at the surface under optimal illumination. In summer these coefficients were only 0.06 to $0.15 \mathrm{~d}^{-1}$ (average $0.09 \mathrm{~d}^{-1}$; Table 5). In autumn they were higher -- about $0.3 \mathrm{~d}^{-1}$. Calculated for the total phytoplankton population in the water col-

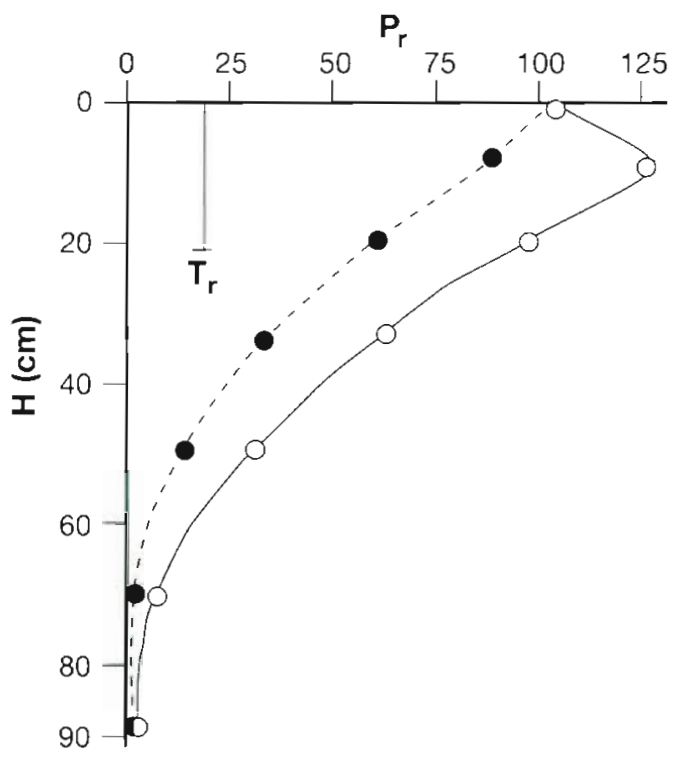

Fig. 3. Dependence of photosynthesis rate $\left(P_{r}\right.$, relative values $)$ in water column of the Campo lagoon upon light attenuation with depth ( $K_{\mathrm{p}}$ curve) on a dull $(\bullet)$ and a bright day $(0)$; $\mathrm{T}_{\mathrm{r}}$ : Secchi disk depth

umn they were only half as much, due to self-shading: 0.05 in summer and 0.14 in autumn.

Because of the extreme density of phytoplankton the Secchi disk depth was only 20 to $30 \mathrm{~cm}$. Thus the depth of the euphotic zone in the lagoons was only 70 to $80 \mathrm{~cm}$, and not down to the bottom as is usual in shallow lagoons. The $K_{\mathrm{t}}$ curves measured on a bright day had a maximum at $10 \mathrm{~cm}$, showing a definite light inhibition near the surface, which was absent on a dull day.

Table 2. Numerical abundance $(\mathrm{N})$ and wet biomass $\left(\mathrm{B}, \mathrm{g} \mathrm{m}^{-3}\right)$ of heterotrophic plankton in the major Comacchio lagoons

\begin{tabular}{|c|c|c|c|c|c|c|c|c|c|c|}
\hline \multirow[t]{2}{*}{ Season } & \multirow[t]{2}{*}{ Lagoon } & \multirow[t]{2}{*}{ Stn no. } & \multicolumn{2}{|l|}{ Bacteria } & \multicolumn{4}{|c|}{ Microplankton } & \multicolumn{2}{|c|}{ Mesozooplankton } \\
\hline & & & $\mathrm{N}\left(10^{6} \mathrm{ml}^{-1}\right)$ & $B$ & $\begin{array}{l}\text { Nanoheter } \\
N\left(10^{6} \mathrm{l}^{-1}\right)\end{array}$ & otrophs & $\begin{array}{c}\text { Ciliates + } \\
\mathrm{N}\left(10^{3} \mathrm{l}^{-1}\right)\end{array}$ & $\begin{array}{l}\text { rotifers } \\
\text { B }\end{array}$ & $N\left(10^{3} \mathrm{~m}^{-3}\right)$ & B \\
\hline \multirow[t]{5}{*}{ August } & Magnavacca & 1 & 83 & 16.6 & 76 & 0.64 & 0.95 & 0.01 & 23.1 & 0.37 \\
\hline & & 2 & 86 & 25.3 & 48 & 0.37 & 0.85 & 0.02 & 19.7 & 0.32 \\
\hline & & 3 & 76 & 14.7 & 33 & 0.50 & 2.50 & 0.03 & 63.3 & 0.96 \\
\hline & Campo & 4 & 63 & 13.0 & 133 & 0.84 & 13.65 & 0.46 & 46.1 & 0.54 \\
\hline & & 5 & 52 & 9.1 & 144 & 0.99 & 17.68 & 0.67 & 2.6 & 0.03 \\
\hline \multirow[t]{6}{*}{ September } & Magnavacca & 6 & 83 & 16.9 & 350 & 2.62 & 0.88 & 0.08 & 4.5 & 0.19 \\
\hline & & 8 & 52 & 9.7 & 222 & 1.66 & 3.15 & 0.04 & 15.2 & 0.35 \\
\hline & & 10 & 71 & 10.7 & 280 & 1.82 & 1.75 & 0.02 & 10.9 & 0.24 \\
\hline & Campo & 11 & 70 & 11.8 & 220 & 1.44 & 1.75 & 0.02 & 10.9 & 0.29 \\
\hline & & 12 & 97 & 17.3 & 240 & 1.40 & 5.83 & 0.04 & 4.6 & 0.07 \\
\hline & & 14 & 73 & 11.9 & 158 & 2.11 & 15.65 & 0.18 & 0.2 & 0.004 \\
\hline \multirow[t]{6}{*}{ November } & Magnavacca & 27 & 28 & 4.0 & 62 & 0.47 & 0.90 & 0.02 & 0.8 & 0.01 \\
\hline & & 28 & 18 & 2.2 & 51 & 0.55 & 0.20 & 0.05 & 1.3 & 0.02 \\
\hline & & 30 & 11 & 1.4 & 34 & 0.36 & 0.30 & 0.01 & 2.0 & 0.03 \\
\hline & Campo & 34 & 14 & 1.7 & 38 & 0.36 & 3.6 & 0.04 & 2.6 & 0.03 \\
\hline & & 35 & 16 & 1.5 & 66 & 0.69 & 5.4 & 0.07 & 2.4 & 0.02 \\
\hline & Marine channel & 36 & 3.5 & 0.4 & 82 & 0.94 & 22.6 & 1.15 & 68.1 & 1.47 \\
\hline
\end{tabular}


Table 3. Mesozooplankton in experimental ponds receiving water from the Campo lagoon, sampled by day (14:00 h) and at night $(22: 00 \mathrm{~h})$; $\mathrm{N}$ : number $\left(\times 10^{3} \mathrm{~m}^{-3}\right)$ : B: biomass $\left.\mathrm{mg} \mathrm{m}^{-3}\right)$

\begin{tabular}{|c|c|c|c|c|c|c|c|c|}
\hline \multirow{2}{*}{$\begin{array}{l}\text { Sampling } \\
\text { time }\end{array}$} & \multirow[t]{2}{*}{ Stn no. } & \multicolumn{2}{|c|}{ Nauplii } & \multicolumn{2}{|c|}{ Copepods } & \multicolumn{2}{|c|}{ Small mysids } & \multirow{2}{*}{$\begin{array}{l}\text { Total biomass } \\
\left(\mathrm{mg} \mathrm{m}^{-3}\right)\end{array}$} \\
\hline & & $\mathrm{N}$ & B & $\mathrm{N}$ & $\mathrm{B}$ & $\mathrm{N}$ & $\mathrm{B}$ & \\
\hline \multirow[t]{3}{*}{$14: 00 \mathrm{~h}$} & 24 & 0.5 & 0.1 & 0.20 & 3 & 0 & 0 & 3 \\
\hline & 25 & 0.5 & 0.1 & 0.10 & 1 & 0 & 0 & 1 \\
\hline & 26 & 0.9 & 0.2 & 0.06 & 3 & 0.03 & 8 & 11 \\
\hline \multirow[t]{3}{*}{$22: 00 \mathrm{~h}$} & 24 & 0.5 & 0.1 & 1.30 & 21 & 0 & 0 & 21 \\
\hline & 25 & 0.5 & 0.1 & 0.40 & 11 & 0 & 0 & 11 \\
\hline & 26 & 0.5 & 0.1 & 2.60 & 34 & 0.15 & 39 & 74 \\
\hline
\end{tabular}

\section{Density and production of bacterioplankton}

The corresponding data are presented in Tables 2 and 3 . In the summer the density of bacterioplankton was extremely high in both lagoons. The total number of bacteria attained a level never recorded before in any natural water body -50 to $97 \times 10^{6} \mathrm{ml}^{-1}$, which is 20 to 30 times more than is usual in eutrophic coastal marine waters. Bacterial biomass was correspondingly high, 10 to $25 \mathrm{~g} \mathrm{~m}^{-3}$; moreover, the average volume of bacterial cells was 1.5 to 2 times greater than in an ordinary basin, being 0.14 to $0.25 \mu^{3}$. Of total bacterioplankton 5 to $10 \%$ was represented by yeast-like eucaryotic microbial cells with clearly visible nuclei when stained with acridine orange. Bacterial production ( $B_{p}$, Table 4) was most intensive in August, when it reached 380 to $605 \mathrm{mg} \mathrm{C} \mathrm{m} \mathrm{m}^{-1}$ or 2 to $3.5 \mathrm{~g} \mathrm{~m}^{-3} \mathrm{~d}^{-1}$ of wet biomass. This represents 5 to 10 times more than ordinarily found in marine eutrophic waters. In November the bacterioplankton density and especially its production decreased several times probably because of the low autumn water temperature $\left(9\right.$ to $\left.11^{\circ} \mathrm{C}\right)$. But even then the total number of bacterioplankton remained at 11 to $28 \times 10^{6} \mathrm{ml}^{-1}$, which has rarely been recorded even in polluted estuarine waters. The specific growth rate of bacterioplankton was low both in summer (average $0.12 \mathrm{~d}^{-1}$ ) and in autumn (average $\left.0.04 \mathrm{~d}^{-1}\right)$.

\section{Zooplankton}

The data on density and composition of zooplankton are given in Table 2 . The microzooplankton was represented in the lagoons mainly by nanoheterotrophs and ciliates. Copepod nauplii were very rare (biomass less than $2 \mathrm{mg} \mathrm{m}^{-3}$ ). Rotifers were found only once at 2 stations in the Campo lagoon (biomass $0.3 \mathrm{~g} \mathrm{~m}^{-3}$ ). In all other samples they were curiously absent both in summer and in autumn. Within the group of nano-

Table 4. Parameters of organic matter production, decomposition and standing stock. PP: primary production; BP: bacterial production; TPM: decomposition rate (total plankton respiration); LOM and SOM: stocks of labile and suspended organic matter

\begin{tabular}{|c|c|c|c|c|c|c|c|c|c|}
\hline Season & Lagoon & Stn no. & $\begin{array}{l}\text { Depth } \\
(\mathrm{m})\end{array}$ & $\left(\mathrm{mg} \mathrm{Cl}^{-1} \mathrm{~d}^{-1}\right)$ & $\left(g \mathrm{C} \mathrm{m}^{-2} \mathrm{~d}^{-1}\right)$ & 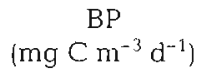 & $\begin{array}{c}\text { TPM } \\
\left(\mathrm{mg} \mathrm{O}_{2} \mathrm{l}^{-1}\right)\end{array}$ & $\begin{array}{c}\text { LOM } \\
\left(\mathrm{mg} \mathrm{Cl}^{-1}\right)\end{array}$ & $\begin{array}{c}\mathrm{SOM} \\
\left(\mathrm{mg} \mathrm{Cl}^{-1}\right)\end{array}$ \\
\hline \multirow[t]{5}{*}{ August } & Magnavacca & 1 & 1.1 & 3.05 & 1.37 & 385 & 3.96 & 19.0 & 24.3 \\
\hline & & 2 & 1.2 & 1.76 & 0.80 & 410 & 4.15 & 21.9 & 30.3 \\
\hline & & 3 & 0.9 & 3.19 & 1.43 & 370 & 3.80 & 29.1 & 23.9 \\
\hline & Campo & 4 & 0.9 & 1.71 & 0.76 & 665 & 5.03 & 17.8 & 25.7 \\
\hline & & 5 & 0.4 & 1.49 & 0.67 & 642 & 5.15 & 24.3 & 23.7 \\
\hline \multirow[t]{6}{*}{ September } & Magnavacca & 6 & 1.2 & 1.25 & 0.56 & 240 & 6.10 & 26.9 & 39.3 \\
\hline & & 8 & 0.9 & 1.23 & 0.56 & 112 & 4.82 & 25.8 & 32.4 \\
\hline & & 10 & 0.8 & 0.81 & 0.45 & 90 & 4.10 & 28.6 & 38.6 \\
\hline & Campo & 12 & 1.1 & 0.74 & 0.26 & 180 & 6.41 & 30.1 & 21.3 \\
\hline & & 13 & 0.9 & 0.84 & 0.29 & 122 & 6.33 & 29.6 & 24.0 \\
\hline & & 14 & 0.3 & 0.93 & 0.20 & 52 & 6.10 & 32.6 & 22.6 \\
\hline \multirow[t]{6}{*}{ November } & Magnavacca & 28 & 1.3 & 1.81 & 0.72 & 24 & 1.85 & 29.0 & 25.5 \\
\hline & & 29 & 1.1 & 1.56 & 0.62 & 22 & 1.94 & 22.3 & 20.4 \\
\hline & & 30 & 0.9 & 2.46 & 0.91 & 32 & 2.29 & 18.4 & 16.0 \\
\hline & Campo & 34 & 0.9 & 1.90 & 0.76 & 14 & 1.54 & 13.3 & 18.6 \\
\hline & & 35 & 0.8 & 0.90 & 0.36 & 16 & 1.28 & 12.9 & 20.3 \\
\hline & Marine channel & 136 & 1.5 & 0.07 & 0.08 & 12 & 0.66 & 1.5 & 1.0 \\
\hline
\end{tabular}


heterotrophs the most numerous were zooflagellates of 3 to $5 \mu \mathrm{m}$ size. The nanoheterotrophs were the only zooplankton group which attained a significant density. In September at some stations it was over $1 \mathrm{~g} \mathrm{~m}^{-3}$, and up to $2.6 \mathrm{~g} \mathrm{~m}^{3}$ at Stn 6. In August and November their biomass was 0.2 to $0.6 \mathrm{~g} \mathrm{~m}^{-3}$ (Table 2). In September their number was as much as 200 to $350 \times 10^{6} \mathrm{l}^{-1}$, and in August and November 30 to $70 \times 10^{6} \mathrm{I}^{-1}$. The ciliate population in the lagoons were very small. Only in summer in the Campo lagoon did it reach a moderate density of 5 to $10 \times 10^{3} \mathrm{l}^{-1}$ (biomass 0.1 to $0.3 \mathrm{~g} \mathrm{~m}^{-3}$ ) at some stations. At other stations the biomass was less than 30 to $40 \mathrm{mg} \mathrm{m}^{-3}$. In most samples ciliates were represented by a medium size (30 to $60 \mu \mathrm{m}$ ) Strombidium sp. In samples from the Campo lagoon Triarina fusus was also present. No tintinnids were recorded.

Net mesozooplankton also appeared to be surprisingly scarce in the lagoons (Table 2). The marine waters entering the lagoons via the channels contained a rich copepod population with biomass over $1 \mathrm{~g} \mathrm{~m}^{-3}$ (Table 2, Stn 36). Thus the largest mesozooplankton biomass was recorded at sites in both lagoons adjacent to the channels (Stn 3 and 4, Table 2). Probably the mesozooplankton in samples collected at more distant stations had the same origin. The copepods in these samples had the same taxonomic composition with predomination of Acartia sp. Most of them had a degenerated appearance, some with broken antennae, and having a blackish color or apparently dead. A scarcity of nauplii (Table 3 ) also indicated that the copepods did not breed in the lagoons. Larger numbers of nauplii were also recorded at Stns 31 and 34 near the marine channels. At other stations they were rare - less than $1 \mathrm{l}^{-1}$. In September at some stations early decapod larvae (zoea) were also recorded, numbering 30 to 100 per $\mathrm{m}^{3}$ (biomass 70 to $150 \mathrm{mg} \mathrm{m}^{-3}$ ). Other representatives of mesozooplankton such as veligers or trocophores were absent in samples taken with a plankton net of $40 \mu \mathrm{m}$ mesh, which should catch them if present. The demersal zooplankton appeared to be surprisingly poor. Zooplankton in nocturnal. catches in the experimental ponds adjacent to the lagoon of Campo were found to be as scarce as in diurnal ones (Table 3), except for the presence of some small mysids at 1 station out of 3 thus sampled.

\section{Stock of organic matter and its decomposition rates}

The stock of labile organic matter (LOM) in the lagoons was found to be very high: 20 to $30 \mathrm{mg} \mathrm{Cl}^{-1}$ in summer and 12 to $22 \mathrm{mg} \mathrm{Cl}^{-1}$ in late autumn, i.e. 10 to 20 times more than is usual in coastal eutrophic waters. At $\operatorname{Stn} 27$, where wind driven phytoplankton accumulated in November, it was even $29 \mathrm{mg} \mathrm{C} \mathrm{l}^{-1}$ (Table 4) The corresponding BOD-30 values were about 50 to 60 $\mathrm{mg} \mathrm{O} \mathrm{I}^{-1}$ in comparison with 3 to $5 \mathrm{mg} \mathrm{O}_{2} \mathrm{l}^{-1}$ in ordinary eutrophic coastal waters (Zsolnay 1975, Sorokin et al. 1983, Tchebotarev \& Sorokin 1983).

The stock of suspended organic matter varied in the lagoons within the range 12 to $30 \mathrm{mg} \mathrm{Cl}^{-1}$ (Table 4). A reduced content was recorded in November, when the phytoplankion density decreased. Thus the content of suspended organic matter was 30 to 50 times more than it was in ordinary eutrophic marine waters (Romankevich 1977; see Table 4, Stn 36) such as the Magnavacca lagoon in August. The ratio of total plankton biomass to suspended organic matter (both expressed in carbon units) reached 75 to $90 \%$ in the Magnavacca lagoon in August. This shows that the larger part of suspended organic matter was comprised by the living plankton biomass, dominated by the picocyanobacteria. In September and November the living biomass comprised 25 to $50 \%$ of suspended organic carbon. On average its value was about $40 \%$ - also a very high value (Table 5).

Total plankton respiration (TPM) as a measure of the decomposition rate in summer ranged from 4 to $6 \mathrm{mg}$ $\mathrm{O}_{2} \mathrm{I}^{-1}$ at different stations, which corresponded to between 60 and $80 \%$ of oxygen saturation in saline

Table 5. Basic ratios characterizing structure and functioning of the Comacchio lagoonal ecosystem calculated as averages for stations

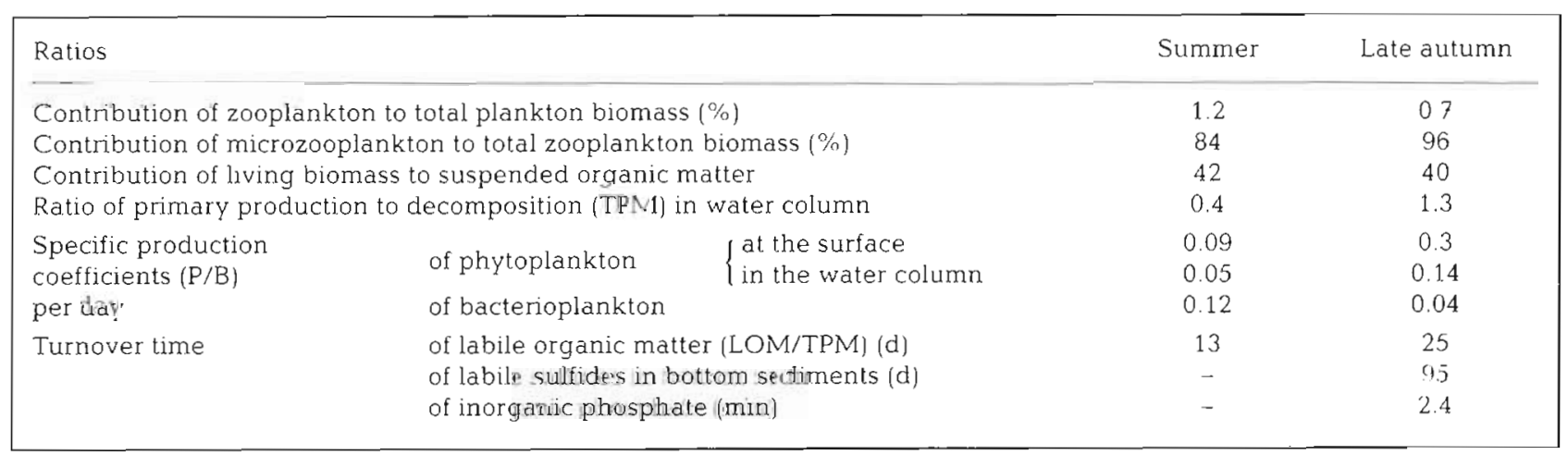


water at $26^{\circ} \mathrm{C}$ (Table 4 ). In September at Stns 11 and 12 in the Campo lagoon, which receive waste waters from the fish culture plant, it reached 10.5 to $11.5 \mathrm{mg} \mathrm{O}_{2} \mathrm{l}^{-1} \mathrm{~d}^{-1}$, or about $150 \%$ of the oxygen saturation value. Calculated per $\mathrm{m}^{2}$ the decomposition rate was 3 to 10 $\mathrm{g} \mathrm{O}_{2} \mathrm{~d}^{-1}$ or 1 to $4 \mathrm{~g} \mathrm{C} \mathrm{d}^{-1}$ in the water column only. However, a significant oxygen consumption should also be expected by the bottom sediments of the lagoons which are enriched with organic matter and with labile sulfides (see Table 10). Therefore, for estimation of total oxygen uptake rates the contribution of bottom sediments also needs to be be estimated. To measure it we sampled undisturbed sediment cores 8 $\mathrm{cm}$ in diameter with a column of water. The cores, with capped bottoms were brought to the laboratory. The upper water was siphoned out and then replaced, being careful that no air bubbles remained. One empty bottle was also filled in the same way as a control without mud. Following incubation for several hours the decrease of oxygen in the bottles was estimated by Winkler titration in subsamples siphoned out from them. Results showed that the oxygen consumption by the bottom surface varied at stations within the narrow range of 1.3 to $1.8 \mathrm{~g} \mathrm{O}_{2} \mathrm{~m}^{-2} \mathrm{~d}^{-1}$ in comparison with that in the water column of 3.8 to $10.2 \mathrm{~g} \mathrm{O}_{2} \mathrm{~m}^{-2} \mathrm{~d}^{-1}$. This indicates that the contribution to oxygen uptake by bottom sediments varied at different stations from 11 to $48 \%$ (Table 6). During the core-sampling we were surprised by the discovery of algo-bacterial mats on the surface of black bottom muds in deeper parts of lagoons at depths of 1.1 to $1.4 \mathrm{~m}$, which had appeared even in conditions of frequent and strong wave turbulence. The mats appeared as a quite structured blackgreenish cover about 0.7 to $0.8 \mathrm{~cm}$ thick. They consisted of filamentous cyanobacteria, sulfur bacteria and diatoms, and were populated by small nematodes

The high rates of respiratory oxygen consumption against the background of a high photosynthetic oxygen production of some 1 to $2 \mathrm{~g} \mathrm{O}_{2} \mathrm{~m}^{-2} \mathrm{~d}^{-1}$ resulted in drastic diurnal fluctuations of dissolved oxygen content in the water column of the lagoons. In the Magnavacca lagoon, with a more intensive photosynthesis in the evening at the surface, the oxygen content was 8.4 to $9.3 \mathrm{mg} \mathrm{O}_{2} \mathrm{l}^{-1}$ or some 110 to $120 \%$ of saturation in the whole water column down to the bottom, while in the morning it dropped to between 1.2 and $3.6 \mathrm{mg} \mathrm{O}_{2}$ $\mathrm{l}^{-1}$, also in the whole water column, despite quite intensive wind mixing during the observations. In the lagoon of Campo where the water column oxygen con- sumption was about double that in Magnavacca, the nocturnal depletion was even more - down to $0.5 \mathrm{mg}$ $\mathrm{O}_{2} \mathrm{l}^{-1}$ near the bottom (Tables 4 \& 7) This means that in calm weather, at least in the bottom layer in summer, complete anoxia could be expected as a common phenomenon in large areas of the Comacchio lagoons. It is no wonder therefore that the benthic fauna was drastically depleted during the period of the catastrophical cyanobacterial bloom. With the high rate of decomposition in the Campo lagoon the deep nocturnal oxygen depletion was not compensated even by the daytime photosynthetic production. Thus the oxygen content there, even in windy weather in the evening, hardly reached $100 \%$ of saturation even at the surface and remained at 3 to $5 \mathrm{mg} \mathrm{O} \mathrm{I}^{-1}$ near the bottom.

The decomposition rate in the water column in summer, not even taking into account the bottom oxygen consumption, was 1.5 to 4 times more than the primary production. The former ratio applies to the Magnavacca lagoon, with a lesser anthropogenic impact, and the latter to the Campo lagoon, which receives waste waters from the fish culture plant. An average ratio of primary production to decomposition calculated per station in both lagoons was 0.4 in summer. By late autumn it was 1.3 , since at that time decomposition processes were inhibited in both lagoons by the low

Table 7. Diurnal changes in oxygen concentration in lagoon waters in mid September

\begin{tabular}{|c|c|c|c|c|}
\hline \multirow{2}{*}{$\begin{array}{l}\text { Lagoon } \\
\text { Magnavacca }\end{array}$} & \multirow{2}{*}{$\begin{array}{l}\text { Stn no. } \\
\text { a } 8\end{array}$} & \multirow{2}{*}{$\begin{array}{c}\begin{array}{c}\text { Time } \\
\text { of day }\end{array} \\
\text { 19:40 h } \\
07: 40 \mathrm{~h}\end{array}$} & \multicolumn{2}{|c|}{$\begin{array}{l}\mathrm{O}_{2} \text { contents in water }\left(\mathrm{mg} \mathrm{l}^{-1}\right) \\
\text { Surface } 5 \mathrm{~cm} \text { above bottom }\end{array}$} \\
\hline & & & $\begin{array}{l}8.65 \\
2.79\end{array}$ & $\begin{array}{l}8.55 \\
1.23\end{array}$ \\
\hline & 10 & $\begin{array}{l}20: 00 \mathrm{~h} \\
07: 50 \mathrm{~h}\end{array}$ & $\begin{array}{l}9.33 \\
3.62\end{array}$ & $\begin{array}{l}8.42 \\
2.79\end{array}$ \\
\hline \multirow[t]{2}{*}{ Campo } & 11 & $\begin{array}{l}20: 10 \mathrm{~h} \\
07: 00 \mathrm{~h}\end{array}$ & $\begin{array}{l}6.67 \\
2.12\end{array}$ & $\begin{array}{l}3.04 \\
0.46\end{array}$ \\
\hline & 13 & $\begin{array}{l}20: 20 \mathrm{~h} \\
07: 05 \mathrm{~h}\end{array}$ & $\begin{array}{l}7.67 \\
3.96\end{array}$ & $\begin{array}{l}5.39 \\
0.58\end{array}$ \\
\hline
\end{tabular}


November temperatures, while primary production remained high (Table 4 ). The rate of decomposition in autumn was 2 to 3 times less in comparison with summer, being between 1.3 and $1.9 \mathrm{mg} \mathrm{O}_{2} \mathrm{l}^{-1}$.

\section{Inorganic phosphorus dynamics}

A very specific feature of the lagoonal ecosystem during the picocyanobacterial bloom was its phosphorus metabolism. The standing stock of phosphorus was kept by the planktonic communities in its organic form. The content of organic phosphorus in lagoonal waters was quite large in conjunction with the high biomass of phytoplankton and bacteria. The total content of organic phosphorus was 8 to $9 \mu \mathrm{g}$-at. $\mathrm{P} \mathrm{I}^{-1}$, and 60 to $80 \%$ of this was found in the particulate fraction, e.g. in plankton (Table 8). The inorganic phosphorus content in water in November was negligible. In most samples it was close to the analytical zero. Only in rare cases was it more than $0.1 \mu$ mol $\mathrm{l}^{-1}$, i.e the $\mathrm{PO}_{4}-\mathrm{P}$ concentration limited phytoplankton growth (Thomas $\&$ Dodson 1969). The high phototrophic and microbial production in the lagoonal waters inevitably required a correspondingly high flow of phosphorus. Under the above conditions of a low ambient $\mathrm{PO}_{4}$ - $\mathrm{P}$ stock this could be provided only by high turnover rates. In fact experiments done with ${ }^{32} \mathrm{P}$-label revealed that, within the range of concentration close to ambient $(0.02$ to $0.15 \mu \mathrm{mol} \mathrm{l}^{-1}$ ), even in the low temperatures in November $\left(11\right.$ to $\left.12^{\circ} \mathrm{C}\right)$, the turnover time of $\mathrm{PO}_{4}-\mathrm{P}$ was only 2 to $3 \mathrm{~min}$, while in a normally structured pelagic community in water of the marine channel at Stn 36 it was over $40 \mathrm{~h}$ (Table 8 ). The labeled $\mathrm{PO}_{4^{-}}{ }^{32} \mathrm{P}$ added to the sample was 90 to $95 \%$ consumed within only 5 to 10 min (Fig. 4). The uptake rate $\left(A_{1}\right)$ of $\mathrm{PO}_{4}-\mathrm{P}$ within the range of ambient concentrations estimated by exposure times less than 1 min (linear uptake part of the curve, Fig, 4) varied from 0.3 to $1 \mu \mathrm{g} \mathrm{P} \mathrm{min}^{-1}$ (Table 8).

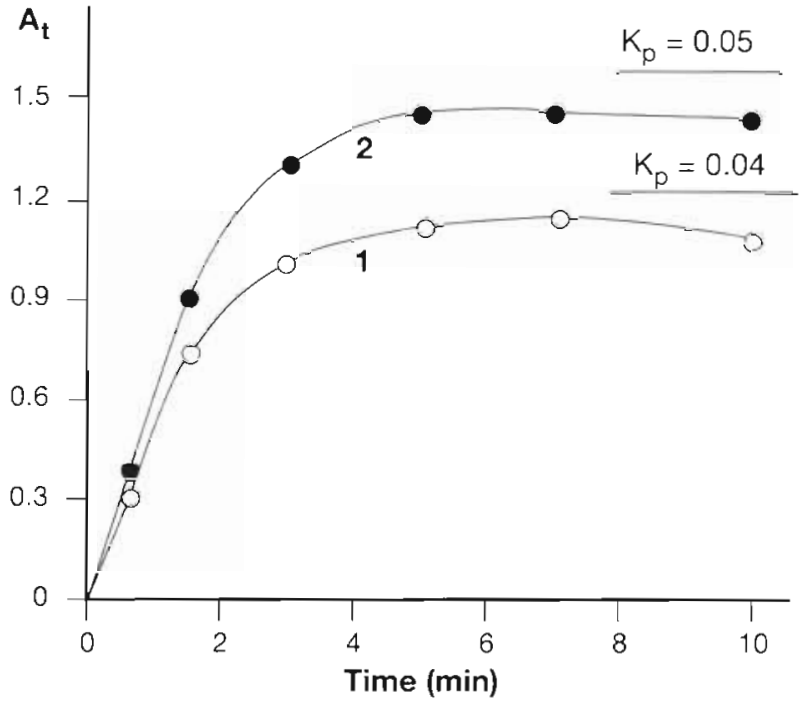

Fig. 4. Time course curves of $\mathrm{PO}_{4}-\mathrm{P}$ uptake $\left(A_{i} ; \mu \mathrm{g} \mathrm{Pl}^{-1}\right)$ in water samples taken at Stns 24 (1) and 26 (2): $K_{\mathrm{p}}$ : ambient initial $\mathrm{PO}_{4}-\mathrm{P}$ content in the sample $\left(\mu \mathrm{mol} \mathrm{l}^{-1}\right)$

Uptake rates in water samples with artificially elevated initial $\mathrm{PO}_{4}-\mathrm{P}$ content (up to above-natural levels of 10 to $30 \mu \mathrm{mol} \mathrm{l}^{-1}$ ) were also estimated in order to evaluate the potential capacity of microplankton communities in the blooming lagoons to take up and retain inorganic phosphate. Results showed that a maximum uptake rate, attained when its content in water was 8 to $10 \mu \mathrm{mol} \mathrm{l} \mathrm{l}^{-1}$, was close to 3 to $4 \mu \mathrm{g} \mathrm{P} \mathrm{l}^{-1}$. This implies a turnover time of even this large stock of $\mathrm{PO}_{4}-\mathrm{P}$ of about 1 h (Table 9). At such a speed of uptake, which was some 2 orders more than that in a normal coastal waters, the initial content of $\mathrm{PO}_{4}$-P added of 4 to $8 \mu \mathrm{mol}$ $\mathrm{l}^{-1}$ was depleted in samples of blooming water down to analytical zero in some 3 to $8 \mathrm{~h}$ (Fig. 5). With initial $\mathrm{PO}_{4}-\mathrm{P}$ contents over $30 \mu \mathrm{mol} \mathrm{l^{-1 }}$ it was depleted by about $25 \mathrm{umol}$ and then reached a plateau. Thus the latter amount characterized the potential capacity of the microplankton community to take up and retain phos-

Table 8. Uptake rates $\left(A_{t}\right)$ turnover time of inorganic phosphate (TP) and stock of organic phosphorus in waters of Comacchio lagoons in November at water temperature 10.5 to $11^{\circ} \mathrm{C}$. $K_{\mathrm{p}}$ : content of $\mathrm{PO}_{4} \mathrm{P}$ in water after addition of 'working' solution of labeled phosphate

\begin{tabular}{|c|c|c|c|c|c|c|}
\hline Lagoon & Stn no. & $\begin{array}{c}K_{\mathrm{p}} \\
\left(\mu \mathrm{mol} \mathrm{l} \mathrm{l}^{-1}\right)\end{array}$ & $\begin{array}{c}A_{1} \\
\left.(\mu \mathrm{g} \mathrm{P}]^{-1} \mathrm{~min}^{-1}\right)\end{array}$ & $\underset{(\min )}{\mathrm{TP}}$ & $\begin{array}{l}\text { Stock of organic } p \\
\text { in intact samples }\end{array}$ & $\begin{array}{l}\text { phorus ( } \mu \mathrm{g} \text {-at. } \mathrm{P} \mathrm{l}^{-1} \text { ) } \\
\text { in filtered samples }\end{array}$ \\
\hline $\begin{array}{l}\text { Experimental } \\
\text { ponds }\end{array}$ & $\begin{array}{l}24 \\
25\end{array}$ & $\begin{array}{l}0.02 \\
0.06\end{array}$ & $\begin{array}{l}0.39 \\
0.81\end{array}$ & $\begin{array}{l}1.6 \\
2.3\end{array}$ & $\begin{array}{l}8.5 \\
7.9\end{array}$ & $\begin{array}{l}3.0 \\
3.2\end{array}$ \\
\hline Magnavacca & $\begin{array}{l}27 \\
28 \\
29 \\
30\end{array}$ & $\begin{array}{l}0.07 \\
0.02 \\
0.06 \\
0.04\end{array}$ & $\begin{array}{l}0.74 \\
0.30 \\
1.03 \\
0.48\end{array}$ & $\begin{array}{l}2.9 \\
2.1 \\
1.8 \\
2.6\end{array}$ & $\begin{array}{l}9.3 \\
8.0 \\
7.8 \\
7.5\end{array}$ & $\begin{array}{l}1.4 \\
1.6 \\
2.6 \\
3.0\end{array}$ \\
\hline Campo & $\begin{array}{l}34 \\
35\end{array}$ & $\begin{array}{l}0.07 \\
0.02\end{array}$ & $\begin{array}{l}0.73 \\
0.36\end{array}$ & $\begin{array}{l}2.6 \\
1.7\end{array}$ & $\begin{array}{l}8.5 \\
8.1\end{array}$ & $\begin{array}{l}1.5 \\
2.9\end{array}$ \\
\hline
\end{tabular}


Table 9. Time course of $\mathrm{PO}_{4}-\mathrm{P}$ uptake $(A$,$) and its turn-$ over time (TP) in water taken at Stn 24 and enriched with phosphate. $K_{\mathrm{p}}$ : initial $\mathrm{PO}_{4}-\mathrm{P}$ content in water

\begin{tabular}{|cccc|}
\hline $\begin{array}{c}K_{\mathrm{p}} \\
\left(\mu \mathrm{mol} \mathrm{I}^{-1}\right)\end{array}$ & $\begin{array}{c}\text { Exposure time } \\
(\mathrm{min})\end{array}$ & $\begin{array}{c}\mathrm{A}_{1} \\
\left.(\mu \mathrm{g} \mathrm{P})^{-1} \mathrm{~min}^{-1}\right)\end{array}$ & $\begin{array}{c}\mathrm{TP} \\
(\mathrm{min})\end{array}$ \\
\hline 4.0 & 3 & 2.63 & 48 \\
& 10 & 2.72 & 47 \\
8.0 & 30 & 2.31 & 54 \\
& 3 & 4.24 & 59 \\
& 23 & 4.14 & 60 \\
& 40 & 3.50 & 70 \\
\hline
\end{tabular}

phate. The uptake of such an amount of $\mathrm{PO}_{4}-\mathrm{P}$ should entail a rise of organic phosphorus content in plankton (and also the C:P ratio in its substance) by 3 to 5 times.

\section{Organic matter and sulfides in bottom sediments}

The content of organic matter in bottom sediments of the lagoons was found to be extremely high, especially in deeper areas where the bottom was covered by black mud with signs of algo-bacterial mats forming (Table 10 ). In upper layers it attained 17 to $23 \%$, i.e. close to that in lake sapropels and 10 to 20 times more than usual in estuarine sediments (Romankevich 1977). Even in shallow lagoonal sediments containing a significant shell fraction it was still high - over 7 to $10 \%$ of dry weight. In the underlying sediments at core depths $>5$ to $7 \mathrm{~cm}$ the content of organic matter was found to be only 0.6 to $4 \%$, which was close to a normal level in coastal marine sediments.

Table 10. Contents of organic matter and labile sulfides in bottom sediments of the Comacchio lagoons. $K_{\text {org }}$ : percentage of organic matter in dry sediment; $\mathrm{KS}$ : contents of labile sulfides ( $\mathrm{mg} \mathrm{S}^{2-} \mathrm{dm}^{-3}$ wet silt); RS: rate of sulfide production in sediments ( $\mathrm{mg} \mathrm{S}^{2-} \mathrm{dm}^{-3}$ wet silt $\mathrm{d}^{-1}$ ); TS: turnover time of labile sulfide stock in sediments (d)

\begin{tabular}{|lccrrrr|}
\hline Lagoon & Stn no. & $\begin{array}{c}\text { Depth layer in } \\
\text { the core }(\mathrm{cm})\end{array}$ & \multicolumn{1}{c}{$K_{\text {org }}$} & KS & RS & TS \\
\hline Magnavacca & 28 & $0-2$ & 17.2 & 495 & 17.20 & 29 \\
& 29 & $0-2$ & 19.0 & 420 & 19.00 & 22 \\
& 30 & $0-2$ & 7.3 & 894 & 7.26 & 123 \\
& $30 \mathrm{~b}$ & $5-7$ & 4.0 & 1060 & 4.04 & 260 \\
& & $0-2$ & 24.0 & 715 & 23.90 & 30 \\
& 31 & $0-2$ & 8.9 & 1218 & 8.90 & 136 \\
& & $5-7$ & 1.9 & 315 & 1.93 & 163 \\
& & $10-12$ & 0.9 & 518 & 0.90 & 645 \\
& $31 \mathrm{a}$ & $0-2$ & 4.2 & 861 & 4.20 & 205 \\
& 34 & $0-2$ & 17.9 & 990 & 17.86 & 55 \\
& $34 \mathrm{a}$ & $0-2$ & 11.4 & 1216 & 11.42 & 106 \\
& & $5-7$ & 0.6 & 946 & 0.62 & 1520 \\
& 35 & $0-2$ & 12.8 & 1590 & 12.8 & 124 \\
& & & & & & \\
\end{tabular}

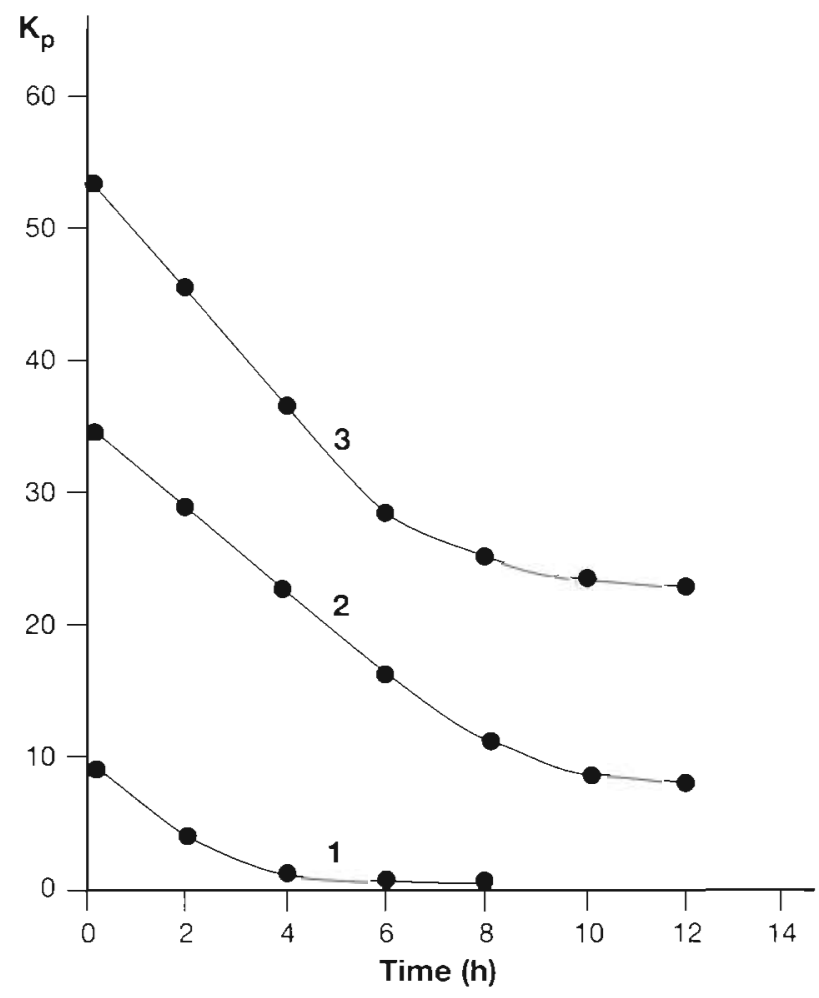

Fig. 5. Time course of depletion of absolute $\mathrm{PO}_{4}-\mathrm{P}$ concentration in water samples $\left(K_{\mathrm{p}}\right)$ taken at $\operatorname{Stn} 24$ and enriched with phosphate up to levels of: $9.7 \mu \mathrm{mol} \mathrm{l}^{-1}(1), 34 \mu \mathrm{mol} \mathrm{l}^{-1}(2)$ and $53 \mu \mathrm{mol} \mathrm{l}^{-1}(3)$

The stock of labile acid-soluble sulfides in the upper layer of bottom sediments was about $1 \mathrm{~g} \mathrm{~S}^{2-} \mathrm{dm}^{-3}$ of wet silt. At some stations it reached 1.2 to $1.6 \mathrm{~g} \mathrm{~S}^{2-}$ $\mathrm{dm}^{-3}$ (Table 10). Such a high level of sulfide content could be readed only in anthropogenically stressed marine basins (Sorokin 1975, 1982). At 2 out of 3 stations, the sulfide content decreased further down in the sediment column, instead of the usual increase within the core because of oxidation. This is evidence that the build-up of sulfide in the upper layer of sediments in the lagoons is a recent phenomenon connected with the acceleration of sulfide production during the bloom. The latter was proved by direct estimation of its rate in the sediments using the radiolabeled sulfate ${ }^{35} \mathrm{SO}_{4}$. The rate of sulfide production due to microbial reduction of sulfate in the upper layer of sediments was at many stations over $10 \mathrm{mg} \mathrm{S}^{2-} \mathrm{dm}^{-3}$ of wet silt per day (Table 10). At Stn 30b it even attained $24 \mathrm{mg} \mathrm{S}^{2-}$, which is a record value in 
marine basins including the meromictic ones (Degens et al. 1992). Further down in the core the rate decreased 3 to 10 times. This indicates that the process of sulfide formation was fuelled in the lagoons by the freshly sedimenting organic matter, consisting mainly of the cyanobacterial biomass (see Table 4).

\section{DISCUSSION}

The data presented above confirm that the lagoons of Comacchio are experiencing an ecological catastrophe caused by an unusually dense picocyanobacterial bloom which has been proceeding there since 1985 (F. Gelli pers. comm,; the bloom continued with the same force in 1995). It has resulted in the formation a new kind of coastal marine ecosystem, which produces mainly the potentially toxic biomass of the invading cyanobacteria, and hydrogen sulfide. A drastic difference in basic characteristics from those of a normal eutrophic lagoonal ecosystem with an ordinary food web is quite obvious (Table 11). This kind of ecosystem seems to be a new one not only for natural, but also perhaps for anthropogenically stressed estuarine environments. Periodical cyanobacterial blooms, stimulated by eutrophication (de Kloet et al. 1984), are usually caused by a larger colonial or coenobial species such as Aphanisomenon or Microcystis, and are rather temporal phenomena. They do not substantially change the biological regime. We had previously observed a similar kind of ecosystem, absolutely dominated by a quasipermanent picocyanobacterial bloom with a biomass over $30 \mathrm{~g} \mathrm{~m}^{-3}$, but in an extreme sulfide environment in the crater lake Green. This lake is situated in the caldera of an active volcano on Raoul. Island (Kermadek Islands, SW Pacific). The lake had a water temperature of about $35^{\circ} \mathrm{C}$, and received hot sulfidecontaining water from surrounding thermal vents (Sorokin et al. 1994). This kind of ecosystem does not show any significant successional changes. Its main characteristics, such as the composition and density of bloom, a negligible density of zooplankton, and extremely high rates of metabolism by depleted inorganic nutrients, appeared to be practically the same in summer and in late autumn.

We had an opportunity to investigate the microplankton and the microbial sulfate reduction in the Comacchio lagoons in 1979, before the cyanobacterial bloom started (Sorokin \& Bilio 1981). At that time definite signs of hyper-eutrophication also appeared in these lagoons due to the influence of intensive fish culture discharges. The changes were especially evident in the lagoon of Campo into which they flow. In this lagoon the phytoplankton was practically absent, having been replaced by several species of Euglena, reflecting a high ievei of eutrophicalion. Water of this lagoon contained an abundant population of ciliates with a biomass up to $2.7 \mathrm{~g} \mathrm{~m}^{-3}$ and moderately abundant bacterioplankton (Table 12). In the Magnavacca lagoon a very dense bloom of chrysomonadic phytoflagellates proceeded with a biomass about $20 \mathrm{~g} \mathrm{~m}^{-3}$. The bottom vegetation was still intact here, as well as the zoobenthos (Cerastoderma), but sulfate reduction had also started and the sulfides in the sediments had begun to incease. In the fish culture ponds their contents had also reached a critical level of 2 to $3 \mathrm{~g} \mathrm{~S}^{2-}$

Table 11. Comparison of basic characteristics of the Comacchio lagoon ecosystem during the catastrophic cyanobacterial bloom with those of a 'healthy' eutrophic lagoon with normal biological regıme, given as ranges of values durng summer

\begin{tabular}{|c|c|c|}
\hline Parameter & $\begin{array}{l}\text { Comacchio } \\
\text { lagoons }\end{array}$ & $\begin{array}{l}\text { Lagoon with } \\
\text { normal regime }\end{array}$ \\
\hline No. of dominating phytoplankton species & $2-3$ & $5-10$ \\
\hline Biomass of phytoplankton $\left(\mathrm{g} \mathrm{m}^{-3}\right)$ & $60-300$ & $1-10$ \\
\hline Biomass of bacterioplankton $\left(\mathrm{g} \mathrm{m}^{-3}\right)$ & $5-25$ & $0.5-2$ \\
\hline Biomass of rotifers $\left(\mathrm{g} \mathrm{m}^{-3}\right)$ & $0-0.1$ & $0.5-1$ \\
\hline Biomass of ciliates $\left(\mathrm{mg} \mathrm{m}^{-3}\right)$ & $20-100$ & $200-800$ \\
\hline Biomass of holoplanktonic mesozooplankton $\left(\mathrm{mg} \mathrm{m}^{-3}\right.$ ) & $30-100$ & $500-1500$ \\
\hline Biomass of demersal meroplankton $\left(\mathrm{g} \mathrm{m}^{-3}\right)$ & $0-0.05$ & $2-20$ \\
\hline Biomass of zoobenthos $\left(\mathrm{g} \mathrm{m}^{-3}\right)$ & $2-6$ & $50-300$ \\
\hline Biomass of macrophytes and seagrasses $\left(\mathrm{g} \mathrm{m}^{-2}\right)$ & 0 & $300-3000$ \\
\hline Stock of labile organic matter in water ( $\mathrm{mg} \mathrm{Cl}^{-1}$ ) & $20-30$ & $1.5-2$ \\
\hline Stock of organic carbon in the sediments ( $\%$ of dry weight) & $8-15$ & $0.5-2$ \\
\hline Stock of suspended organic matter in water column ( $\mathrm{mg} \mathrm{Cl}^{-1}$ ) & $20-30$ & $0.3-1$ \\
\hline Stock of acid-soluble sulfides in bottom sediments ( $\mathrm{mg} \mathrm{S} \mathrm{dm}{ }^{-3}$ of wet silt) & $800-1500$ & $50-200$ \\
\hline Primary production by phytoplankton in upper layer $\left(\mathrm{mg} \mathrm{C} \mathrm{m}^{-3} \mathrm{~d}^{-1}\right)$ & $800-3000$ & $50-200$ \\
\hline Specific production of phytoplankton in water column $\left(\mathrm{d}^{-1}\right)$ & $0.03-0.06$ & $0.5-0.8$ \\
\hline Share of zooplanktonic total plankton biomass $(\%)$ & $0.8-1.5$ & $20-50$ \\
\hline Direct grazing of primary production by phytoplankton (\%) & $0.1-0.3$ & $20-50$ \\
\hline Turnover time of phosphate in water column & $2-3 \min$ & $20-60 \mathrm{~h}$ \\
\hline
\end{tabular}


Table 12. Data on microplankton and sulfate reduction in the Comacchio lagoon in May 1979 (Sorokin \& Bilio 1981). B: biomass ( $\mathrm{mg} \mathrm{\textrm {m } ^ { - 3 }}$ wet biomass); CS: content of labile sulfides in upper layer of bottom sediments (mg $\mathrm{S} \mathrm{dm}{ }^{-3}$ of wet silt); RS: rate of their formation due to microbial sulfate reduction ( $\mathrm{mg} \mathrm{S}^{2-} \mathrm{dm}^{-3} \mathrm{~d}^{-1}$ ); ranges of values observed at stations are given

\begin{tabular}{|c|c|c|c|c|c|c|}
\hline \multirow[t]{2}{*}{ Site } & \multicolumn{2}{|c|}{$\begin{array}{l}\text { Sulfate reduction and } \\
\text { sulfides in sediments }\end{array}$} & \multicolumn{2}{|l|}{ Phytoplankton } & \multirow{2}{*}{$\begin{array}{c}\text { Bacterio- } \\
\text { plankton } \\
\text { B }\end{array}$} & \multirow{2}{*}{$\begin{array}{c}\text { Ciliates } \\
\text { B }\end{array}$} \\
\hline & $\mathrm{CS}$ & RS & Dominating groups & B & & \\
\hline Eel culture pond & $1700-3000$ & $6-23$ & Euglena sp. & $300-500$ & $2000-10000$ & $40-1200$ \\
\hline Lagoon of Campo & $600-950$ & $5-13$ & Euglenoids & $1000-4500$ & $1000-1400$ & $360-2750$ \\
\hline Lagoon of Magnavacca & $270-1250$ & $3-13$ & Chrysomonadic phytoflagellates & 22000 & $970-2500$ & $20-560$ \\
\hline
\end{tabular}

$\mathrm{dm}^{-3}$. Thus the environments in the lagoonal area in 1979 also displayed definite signs of destabilization.

The cyanobacterial bloom, which started in the lagoons in 1985, rapidly transformed the ecosystem. The most profound changes were experienced by the zooplankton. All its components, especially those breeding in the lagoon (rotifers, demersal forms of crustaceans) and also the meroplanktonic larvae, which are usually very abundant in lagoons, have been drastically depleted. The obliteration of the 2 latter components of zooplankton was definitely connected with the disappearance of bottom vegetation weeds and grasses, and with the build-up of sulfides in the bottom sediments. The depletion of the benthic fauna was caused by the accumulation of sulfides, by nocturnal anoxia near the bottom in summer and also, probably, by the potential toxicity or poor food quality of the cyanobacterial biomass as a dominating component of particulate food produced in the water column during the bloom (Ayles et al. 1976). The phytoplankton community of the blooming lagoons included one definitely toxic species, Coelosphaerium kützengianum (Elenkin 1938). The food quality of mucous colonial cyanobacteria like Aphanothece or Microcystis is also known to be poor (Sorokin 1968, De Bernardi \& Giussani 1990).

To investigate the possibility of filtering fauna using phytoplankton from the blooming lagoons as food, we measured the rate of its consumption and assimilation in short-term ( $1 \mathrm{~h}$ ) experiments with ${ }^{14} \mathrm{C}$-labeled phytoplankton of water samples taken at Stn 24, using the methodology described by Sorokin (1968). The results, shown in Table 13, proved poor food quality in comparison with other algae, like diatoms of Chlorella. Even with an optimal concentration $6 \mathrm{~g} \mathrm{~m}^{-3}$ wet biomass its assimilation by the bivalve Tapes philippinarum did not cover the energy expenditure for respiration (the value of $G$ was negative). Moreover a significant portion of the assimilated substance of natural phytoplankton in the sample was probably represented by Chlorella and phytoflagellates present in small amounts (see Table 1).

The success of the strategy of the key blooming algae (the picocyanobacteria), a surprisingly time-sta- ble survival and domination, could be seen in their ability to accumulate and reproduce an enormously high biomass through prevention of grazing and by successfully opposing competition from any other plants. This goal was achieved by drastic depletion of animal filtering fauna, both planktonic and benthic. The zooflagellates, which were present in some summer samples in significant amounts, being 2 to $4 \mu \mathrm{m}$ in size, could graze mostly on the bacterioplankton but not on the cyanobacterial cells of about their own size.

Evidence for the apparent inhibiting effect of the picocyanobacteria blooming in the lagoons upon the ciliates was provided by the unusual stability of their populations in bottled water samples. The samples were kept for over a month in natural light without visible changes in density of cyanobacteria in them, while normally the phytoplankton in water sample would be cleared by ciliates within a couple of days. But these water samples behaved like sterile algal cultures.

The competing macro- and microalgae were overwhelmed by the cyanobacteria due to the light attenuation by the latter's huge biomass, by a permanent depletion of nutrients, and by the fuelling of sulfide production with their non-grazed biomass. An excess of sulfides and the free $\mathrm{H}_{2} \mathrm{~S}$ thus produced migrate up the water column and there create a specific sulfur environment which is welcomed by the cyanobacteria (Elorenta 1972, Oren \& Shilo 1979, Cohen et al. 1986), but which inhibits all other eucaryotic competitors or grazers due to the cytochrome poison.

Table 13. Tapes phulppinarum. Elements of food balance for different kinds of food. FR: food ration; A: assimilated food; G: use of assimilated food for growth; all numbers are given as $\mathrm{mg} C$ per $\mathrm{g}$ of clam meat for $24 \mathrm{~h}$; food concentration in experiments: $6 \mathrm{mg} \mathrm{l}^{-1}$ (wet biomass)

\begin{tabular}{|lrrr|}
\hline Kinds of food & FR & A & G \\
\hline Nitzschia & 66.8 & 46.1 & 32.8 \\
Chlorella & 44.0 & 25.5 & 12.2 \\
Phytoplankton from Stn 24 & 10.4 & 4.2 & -9.1 \\
dominated by picocyanobacteria & & & \\
\hline
\end{tabular}


An enormous biomass of picocyanobacteria was built up and supported by rather low specific production rates of some 0.08 to $0.12 \mathrm{~d}^{-1}$ in the water column (Table 5). This phenomenon is usual for pelagic communities with a low grazing pressure (Sorokin 1981). The above values were calculated as the ratio of primary production to biomass. But in fact a significant part of the latter will be produced heterotrophically, if we take into account the ability of cyanobacteria for heterotrophy (Rippka 1972, Ohki \& Katon 1975, Whitton \& Sinclair 1975, Oren \& Shilo 1979, Kuzmenko 1981), and the light deficiency in the water column of the lagoons (cf. Fig. 3). Despite a low specific production, the absolute rates of primary production and decomposition in the lagoons appeared to be at the highest level ever recorded in natural marine basins, even coastal, because of the enormous biomass of phytoplankton and bacterioplankton which this curiously transformed ecosystem managed to support.

The nutrient depletion observed during all periods of the bloom occurred because all the available nutrient stock, which itself was high $\left(8\right.$ to $9 \mu \mathrm{g}$-at. $\mathrm{P} \mathrm{I}^{-1}$, see Table 8), was kept tightly inside the biomass (Riegman 1985). It was recycled within semiclosed microcosms of the cyanobacterial mucous colonies (Khoja \& Whitton 1971, Whitton \& Sinclair 1975, Kuzmenko 1981). The cyanobacteria also easily shift from phototrophy to heterotrophy, and thus are themselves able to recycle the nutrients (Karnaukhov et al. 1980, Carr \& Whitton 1982).

In order to investigate further how the Comacchio lagoonal ecosystem functions we calculated tentative energy balances and composed energy flow schemes. The balances were calculated for summer and late autumn situations at most typical stations in the Magnavacca lagoon, and also for the summer period at stations in the Campo lagoon, which received a large load of external organic matter. For their calculation specific production coefficients (P/B), growth efficiency coefficients $\left(K_{2}\right)$ and assimilability coefficients (I) known from the literature were used (Sorokin 1968, Zaika 1973, Grese 1979, Vinogradov \& Shushkina 1987; Table 14). The production of that part of cyanobacteria fed chemoorganotrophically $\left(P_{\mathrm{c}}\right)$ was calculated via the probable value of their respiration $\left(\mathrm{M}_{\mathrm{c}}\right): P_{\mathrm{c}}=\mathrm{M}_{\mathrm{c}}\left[K_{2} /\left(1-K_{2}\right)\right]$, assuming a value of $K_{2}$ equal to that in bacteria $(0.32$, see below). The value of $M_{c}$ itself was calculated as the difference between the total plankton respiration $\left(M_{1}\right)$ measured by the dark bottle oxygen method (see Table 3 ) and the joint respiration of bacterioplankton $\left(\mathrm{M}_{\mathrm{b}}\right)$ plus the autotrophic part of phytoplankton $\left(M_{p}\right): M_{c}=\left[M_{t}-\left(M_{b}+M_{p}\right)\right]$. The value of $M_{b}$ was found using the values of measured bacterioplankton production $\left(\mathrm{P}_{\mathrm{b}}\right): \mathrm{M}_{\mathrm{b}}=\mathrm{P}_{\mathrm{b}}\left[\left(1-K_{2}\right) / K_{2}\right]$, where $K_{2}=0.32$ (Sorokin 1981).
Table 14. Coefficients used for the energy balance calculations. KB: caloric equivalent of wet biomass (cal $\mathrm{mg}^{-1}$ ) I: assimilability $(A / B) ; P / B$ : specific production; $K_{2}$ : secondary growth efficiency $(\mathrm{P} / \mathrm{A})$, where $\mathrm{A}=$ assimilation, $\mathrm{B}=$ biomass and $\mathrm{P}=$ production

\begin{tabular}{lllll|}
\hline $\begin{array}{l}\text { Components of } \\
\text { ecosystem }\end{array}$ & KB & I & P/B & $K_{2}$ \\
\hline Phytoplankton & 0.7 & - & - & - \\
Bacterioplankton & 0.8 & - & - & 0.3 \\
Microzooplankton & 0.75 & 0.6 & 0.8 & 0.4 \\
Mesozooplankton & 0.9 & 0.4 & 0.05 & 0.5 \\
Benthic bacteria & 1.8 & - & 0.05 & 0.3 \\
Zoobenthos & 0.5 & 0.5 & 0.015 & 0.3 \\
\hline
\end{tabular}

The value of $M_{p}$ was assumed to be $10 \%$ of primary production by phototrophs. The use by the lagoonal ecosystem of external allochthonous organic matter entering the lagoons from the land and from the fish culture ponds was also taken into account. Its values were calculated as the difference between local primary production and the total energy demand of the whole ecosystem (Sorokin 1972).

The results of the balance calculations are given in Table 15 and in Figs. 6 to 8. They show that the blooming picocyanobacteria represented in the ecosystem the main productive and metabolic component. In the lagoon of Campo in summer and in the Magnavacca lagoon in autumn their share even in total plankton respiration was about $70 \%$, while the total share of animal heterotrophs including zoobenthos was only 3 to $5 \%$. The combined food ration of animals was several times less than the combined production of particulate food by microplankton. But, in spite of this obvious discrepancy between the production of particulate food and animal grazing, the ecosystem appeared to be extremely stable and self-sufficient, producing conditions convenient for the dominating picocyanobacteria. A major portion of primary production and of allochthonous organic matter used by microplankton was respired by the heterotrophic part of the picocyanobacterial population and by the bacterioplankton. Between 80 and $90 \%$ of all microbial production must remain unused by the depleted animal grazers. In part it was respired by the microplankton community itself, but a large portion settled to the bottom and was used by microflora in sediments for $\mathrm{H}_{2} \mathrm{~S}$ production. The allochthonous organic matter in the Magnavacca lagoon in summer and autumn provided only 6 to $10 \%$ of the needed energy. But in the Campo lagoon in summer the ambient population of cyanobacteria existed mostly heterotrophically using basically the allochthonous organic matter from the fish culture plant. The water turbidity there was extremely high. and the photosynthetic production in the water column 
Table 15. Elements of energy balance in main components of the Comacchio lagoonal ecosystem. B: biomass; FR: food ration; A: assimilated food; P: production; M: respiration (i.e. metabolism); F: non-assimilated food; $M_{1}$ : integral respiration of all biological community, calculated as $\Sigma \mathrm{M}_{i}$ TPM: total respiration of plankton, measured experimentally; all numbers are given in cal $\mathrm{m}^{-2} \mathrm{~d}^{-1}$

\begin{tabular}{|c|c|c|c|c|c|c|c|c|}
\hline $\begin{array}{l}\text { Lagoon, Stn no., } \\
\text { month, TPM }\end{array}$ & $\begin{array}{l}\text { Components of } \\
\text { ecosystem }\end{array}$ & B & $\mathrm{FR}$ & A & $P$ & M & $\mathrm{F}$ & $\begin{array}{c}\mathrm{M} / \mathrm{M}_{\mathrm{t}} \\
(\%)\end{array}$ \\
\hline Magnavacca, & Phytoplankton & 170000 & - & 14300 & 13000 & 1300 & - & 9 \\
\hline $\operatorname{Stn} 3$ & Heterotrophic cyanobacteria & 17000 & - & 6200 & 2000 & 4250 & - & 29 \\
\hline End of August, & Bacterioplankton & 27000 & - & 10400 & 3400 & 7000 & - & 49 \\
\hline \multirow[t]{4}{*}{$\mathrm{TPM}=13000$} & Microzooplankton & 500 & 1300 & 800 & 400 & 400 & 500 & 3 \\
\hline & Mesozooplankton & 900 & 200 & 80 & 30 & 50 & 120 & 0.3 \\
\hline & Benthic bacteria & 15000 & - & 1900 & 600 & 1300 & - & 9 \\
\hline & Zoobenthos & 2000 & 200 & 100 & 30 & 70 & 100 & 0.7 \\
\hline Campo, & Phytoplankton & 16000 & - & 2600 & 2400 & 200 & 17600 & 1 \\
\hline Stn 12 & Heterotrophic cyanobacteria & 52000 & - & 25800 & 8200 & 17600 & - & 72 \\
\hline Mid-September, & Bacterioplankton & 32000 & - & 5000 & 1600 & 3400 & - & 14 \\
\hline \multirow[t]{4}{*}{$M_{1}=22000$} & Microzooplankton & 1100 & 2600 & 1600 & 800 & 800 & 1000 & 3 \\
\hline & Mesozooplankton & 70 & 20 & 10 & 4 & 5 & 10 & 0.02 \\
\hline & Benthic bacteria & 30000 & - & 3100 & 1000 & 2100 & - & 7.80 \\
\hline & Zoobenthos & 4000 & 600 & 280 & 80 & 200 & 320 & 1.30 \\
\hline Magnavacca, & Phytoplankton & 33000 & - & 9000 & 8000 & 1000 & - & 12 \\
\hline $\operatorname{Stn} 30$ & Heterotrophic cyanobacteria & 8000 & - & 8800 & 2800 & 6000 & - & 69 \\
\hline Mid-November, & Bacterioplankton & 2600 & - & 900 & 300 & 600 & - & 7 \\
\hline \multirow[t]{4}{*}{$M_{1}=7930$} & Microzooplankton & 350 & 1250 & 550 & 250 & 290 & 700 & 3.6 \\
\hline & Mesozooplankton & 30 & 17 & 7 & 3 & 4 & 10 & 0.004 \\
\hline & Benthic bacteria & 6000 & - & 900 & 300 & 600 & - & 11.4 \\
\hline & Zoobenthos & 2000 & 200 & 100 & 30 & 70 & 100 & 1 \\
\hline
\end{tabular}

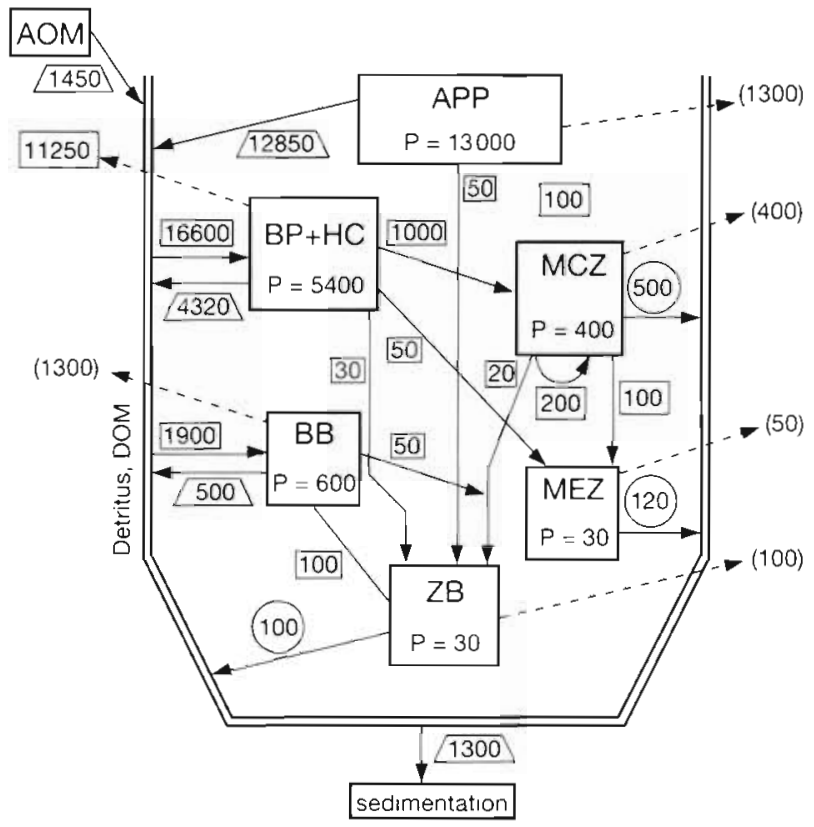

Fig. 6. Scheme of energy flow in the ecosystem of Magnavacca lagoon (Stn 3) in August. P. production; DOM: dissolved organic matter; numbers in squares: food ration of subsequent component of food web; numbers in trapezia: non-grazed production; numbers in circles: non-assimilated part of food ration; numbers in brackets: respiratory losses of assimilated food. All numbers are given as cal m $\mathrm{m}^{-2} \mathrm{~d}^{-1}$ Food web components: APP, phototrophic phytoplankton; BP, bacterioplank-

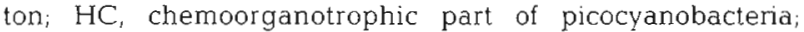
MSZ, microzooplankton; MEZ, mesozooplankton; $B B$, benthic bacteria; ZB, zoobenthos; AOM, allochthonous organic matter was relatively low with a very high rate of total planktonic respiration, over $70 \%$ of which was contributed by heterotrophic cyanobacteria.

A high production rate of the non-grazed excess organic matter in the lagoons during the bloom significantly changed the bottom life and its chemistry. The bottom vegetation died out, the zoobenthos was

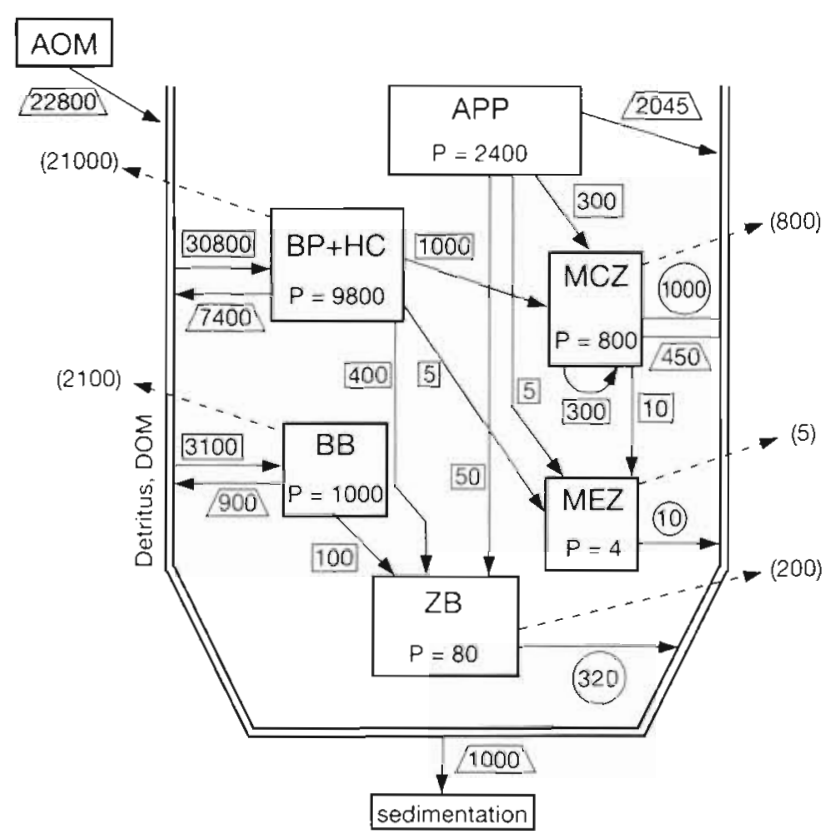

Fig. 7. Scheme of energy flow in the ecosystem of the Campo lagoon (Stn 12) in September; for designations, see Fig. 6 


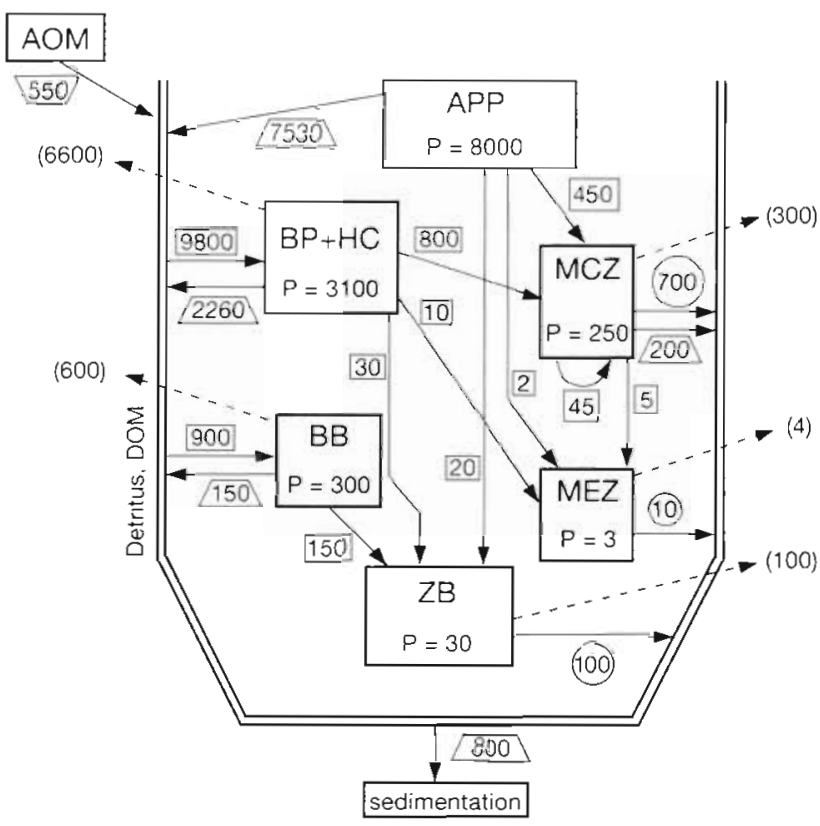

Fig. 8. Scheme of energy flow in the ecosystem of the Magnavacca lagoon (Stn 30) in November, for designations, see Fig. 6

depleted to a negligible amount of a few polychaetes and nematodes. Over the sediment surface the formation of algo-bacterial mats began, which is a feature of suboxic sulfide basins (Cohen \& Rosenberg 1989). An intensive accumulation of organic matter proceeded in the upper 0 to $5 \mathrm{~cm}$ layer of sediments formed during the bloom period (Table 10). It increased the sulfate reduction rate which finally caused a mass mortality of zoobenthos.

A scenario of how the above described man-made ecological catastrophe developed could be as follows. Since ancient times the lagoons have been an area of intensive economic activity, being the location of productive eel, clam and shrimp fisheries and having very limited water exchange with the sea. A complicated system of channels and dikes was constructed in them to regulate the hydrological regime and fish migrations for the benefit of the fisheries. By the early 1970s the experimental plant for intensive eel aquaculture had been established in the Comacchio lagoonal area with the use of the larger lagoons as receipt and selfpurification basins for waste waters. The aquaculture of eels produced large amounts of waste, because there fishes do not take pellets and were fed with fish paste. A large part of it remained uneaten by fish, dissolved in the water, and was discharged into the lagoons with the waste waters. The input of large loads of organic matter into already eutrophic lagoons, which also experienced eutrophication impacts from intensive agricultural activity and had restricted water exchange with the sea, resulted in the build-up of large stocks of nutrients, of labile organic matter and of microbial biomass which could not be consumed and digested by local planktonic and benthic communities aerobically. Thus anaerobic sulfate reduction was triggered in the bottom sediments. A rapid accumulation of labile sulfides and free $\mathrm{H}_{2} \mathrm{~S}$ in sediments began. These developments have been recorded in the lagoons since 1979 (Table 12). Especially high loads of sulfides were recorded in the fish culture ponds. Its oxidation induced formation of anoxic zones and resulted in the disappearance of normal phytoplankton and its zooplankton grazers. Their place was taken by the cyanobacteria, which are resistant to anoxia and sulfides (Carr \& Whitton 1982, Cohen 1984, Schmidt 1988). Their biomass was then pumped out into the Campo lagoon, which also had been destabilized by the waters discharged from the plants (Table 12). Thus the cyanobacterial bloom was started there too, and spread to the large Magnavacca lagoon.

The bloom has been proceeding in these lagoons for about a decade without a visible decrease, and could be assumed to proceed for another decade with a consequent complete collapse of the fisheries and dangor of similar catastrophic events in adjacent lagoonal and coastal basins of the western Adriatic, many of which are also now at the threshold of hypereutrophication due to wastes from numerous aquaculture and other enterprises (UNESCO 1988). Only radical measures could stop the bloom in the Comacchio lagoons. At this point we would recommend the complete draining of the lagoons and the weathering of their bottoms for a couple of years. During this time the remaining eel population could be maintained in the lagoons of Salina if previously prepared for this purpose.

After weathering, the lagoons should be refilled twice with Adriatic water to remove the stock of extra nutrients from the sediments.

Acknowledgements. The authors thank Drs F Ghion, $G$ Ravagnan, G.-P. Ravagnan, L. Pregnolato, F. Gelli, P. Dallocchio, L. Dallavenezia, L. M. Gerasimenko and P. Franco for their assistance. This research was supported by grants from the Emilia Romagna regional administration and from CNR of Italy.

\section{LITERATURE CITED}

Ayles GB, Lark JC, King H (1976) Seasonal mortality of rainbow trout in eutrophic lakes of Canada. J Fish Res Bd Can 33:647-657

Caron DA (1983) Technique for enumeration of nanoplankton using epifluorescence microscopy. Appl environ Microbiol 46:491-498

Carr NG, Whitton BA (1982) The biology of cyanobacteria. Blackwell, Oxford

Cohen Y (1984) Oxygenic and anoxygenic photosynthesis and sulfate reduction in cyanobacterial mats. In: Colwell $R$ 
(ed) Current perspectives in microbial ecology. Am Soc Microbiol, Washington, DC, p 435-441

Cohen Y, Jørgensen BB, Revsbech NB, Poplabvski R (1986) Adaptation to $\mathrm{H}_{2} \mathrm{~S}$ of oxygenic and anoxygenic photosynthesis in cyanobacteria. Appl environ Microbiol 51. $398-407$

Cohen Y, Rosenberg E (1989) Microbial mats. Am Soc Microbiol, Washington, DC

De Bernardi R, Giussani G (1990) Are blue-green algae a suitable food for zooplankton? In: Gulati RD (ed) Biomanipulation - tool for water management. Kluver Acad Press, Amsterdam, p 159-168

Degens ET, Kempe S, Lein A, Sorokin Yu (eds) (1992) Interactions of biogeochemical cycles in aqueous ecosystems. SCOPE-UNEP, Hamburg

de Kloet WA, Boesewinkel-de Bruyn PJ, Salome BL (1984) The phytoplankton and its production rates in Loodsrecht lakes. Verh int Verein theor angew Limnol 22:848-852

Elenkin AA (1930) The blue-green algae. Acad Sci USSR Leningrad (in Russian)

Elorenta P (1972) On the phytoplankton of water polluted by a sulfide cellulose. Ann Bot Fenn 9:20-28

Grese VN (ed) (1979) Fundamentals of biological productivity in the Black Sea. Naukova Dumka, Kiev (in Russian)

Hobbie JE, Daley RJ, Jaspers S (1977) Use of nucleopore filters for counting bacteria by epifluorescence microscopy. Appl environ Microbiol 33:1225-1228

Karnaukhow VN, Martzenjuk PP, Jashin VA (1980) Spectral characteristics of physiological state of cyanobacteria. Physiology of Plants (Moscow) 27(1):11-17 (in Russian)

Khoja TM, Whitton BA (1971) Heterotrophic growth of bluegreen algae. Arch Microbiol 79:280-282

Kuzmenko MI (1981) Mixotrophy in cyanobacteria. Naukova Dumka, Kiev (In Russian)

Onki K, Katon T (1975) Photoorganotrophic growth of a bluegreen algae Anabaena. Plant Cell Physiol 16:53-64

Oren A, Shilo M (1979) Anaerobic heterotrophic dark metabolism of Oscillatoria: sulfur respiration. Arch Microbiol $122.74-84$

Riegman R (1985) Phosphate-phytoplankton interactions. PhD thesis, University of Amsterdam

Rippka R (1972) Photoheterotrophy and chemoheterotrophy among unicellular cyanobacteria. Arch Microbiol 87 $93-98$

Romankevich EA (1977) Geochemistry of organic matter in the ocean. Nauka, Moscow (in Russian)

Schmidt A (1988) Sulfur metabolism in cyanobacteria. In: Backer L, Glazek $M$ (eds) Methods of enzymology, Vol 167 Academic Press, New York, p 572-583

Sorokin Yu I (1960) Vertical distribution of phytoplankton and the primary production in the sea. J Cons Expl Mer 29: $41-65$

Sorokın Yul (1968) The use of ${ }^{14} \mathrm{C}$ in the study of nutrition of aquatic animals. Mitt int Verein theor angew Limnol N16: $1-41$

This article was submitted to the editor
Sorokin Yul (1972) Biological productıvity of Rybinsk Reservoir. In: Kajak Z (ed) Productivity problems of freshwaters Polish Sci Publ (PSN), Warsaw/Cracow, p 493-503

Sorokin Yu I (1975) Sulfide formation and chemical composition of bottom sediments of some Itclian lakes. Hydrobiologia 47:231-240

Sorokin Yu I (1980) Chamber for quantification of planktonic protozoa. Hydrobiol J (Kiev) 16(6):84-86 (in Russian)

Sorokin Yul (1981) Microheterotrophic organisms in marine ecosystems. In: Longhurst A (ed) Analysis of marine ecosystem. Academic Press, Nicw York, p 293-342

Sorokın Yu I (1982) Bacterial sulfate reduction in bottom sedıments in some water basins of Italy. Hydrobiol J (Kiev) 18(4):38-44 (in Russian)

Sorokin YuI (1985) Phosphorous metabolism in planktonıc communities of the eastern tropical Pacific Ocean. Mar Ecol Prog Ser 27:87-97

Sorokin YuI (1987) On the adequacy of ${ }^{14} \mathrm{C}$ method in measurements of primary production. Oceanology (Moscow) $27: 676-682$

Sorokin YuI (1990) Comparative evaluation of isotopic methods for measuring microbial production in the sea. Arch Hydrobiol Beih Ergebn Limnol 34:157-164

Sorokin Yu I, Bilio M (1981) Studies of microbial sulfate reduction and microplankton in the fish culture ponds of Comacchio region. Biologiya Morya (Vladivostok) N2: 50-58 (in Russian)

Sorokin Yul, Mamaeva TI (1980) Rate and efficiency of utilization of labile organic matter by planktonic microflora in peruvian waters. Polskie Arch Hydrobiol 27 : $447-456$

Sorokin Yul, Sorokin PYu, Zakuskina OYu (1994) Microplankton in areas of shallow volcanic activity in the western Pacific. J gen Biol (Moscow) 55:223-242 (in Russian)

Sorokin YuI, Tyapkin VS, Nquen Tak Ahn (1983) Energy interconnection in bottom biocoenoses of coral reefs and adjacent oceanic waters. Biologiya Morya (Vladivostok) N3:29-38 (in Russian)

Tchebotarev YuS, SorokinYuI (1983) Stock of labile organic matter and rate of its decomposition in coastal waters In: Sorokin YuI (ed) Seasonal changes in the Black sea plankton. Nauka, Moscow, p 123-128 (in Russian)

Thomas WH, Dodson AN (1969) Effects of phosphate on cell division rates and yeld of a tropical marine diatom. Biol Bull 134:199-208

UNESCO (1988) UNESCO Bull Mar Sci 49

Vinogradov ME, Shushkina EA (1987) Functioning of epipelagic planktonic communities. Nauka, Moscow (in Russianl

Whitton BA, Sinclair C (1975) Ecology of blue green algae. Sci Progr 62(247):429-446

Zaika VE (1973) Specific production of aquatic invertebrates. Wiley, London

Zsolnay J (1975) Total labile carbon in the Baltic Sea as measured by BOD. Mar Biol 29:125-129

Manuscript first received: February 23, 1995

Revised version accepted: August 29, 1995 